أثر برنامج تعليمي باستخدام التعلم المستند للاماغ على أداء بعض

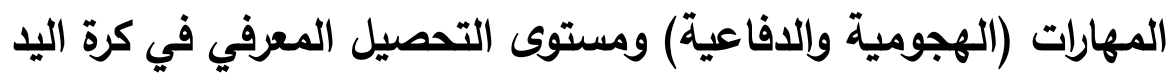

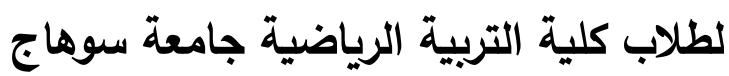

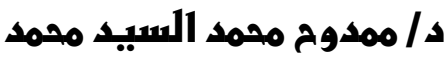

تعد البرامج التعليمية أحد الركائز الأساسية في عملية التخطيط للتعليم

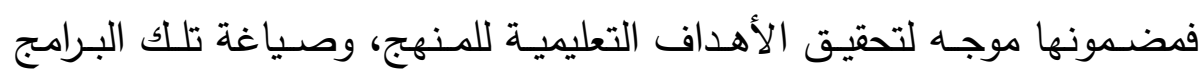
يتضمن مراعاة الأهداف وأساليب التدريس والإمكانات المتوفرة، وأساليب التقويم.

$(r \cdot: 10)$

وعملية تدريس التربية الرياضية على الرغم من سهولتها الظاهريـة، إلا

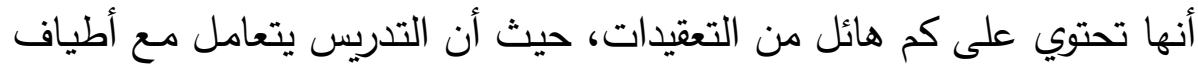

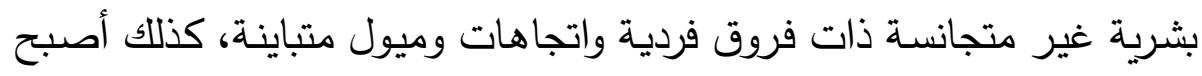

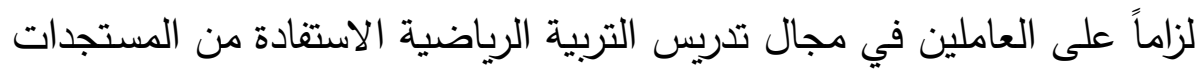

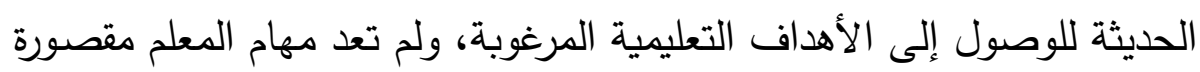

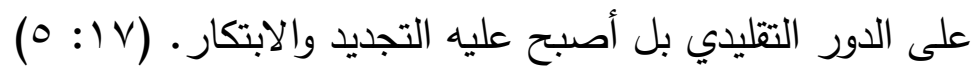

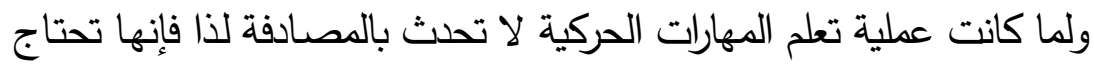
إلى دراسـة علميـة ققيقة ودرايـة تامـة بـالنواحي الفسيولوجية والميكانيكيـة المرتبطــة بالأداء الحركي، خاصـة التي تتـاول أجهزة التحكم الحركي وفسيولوجية الجهازين

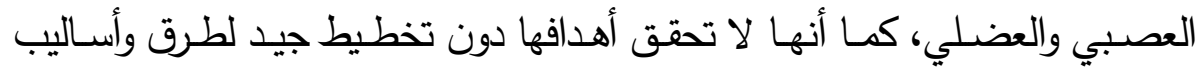

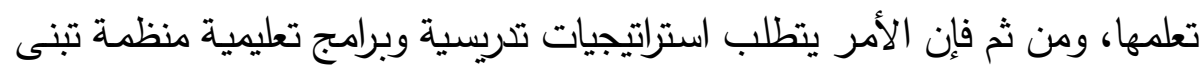

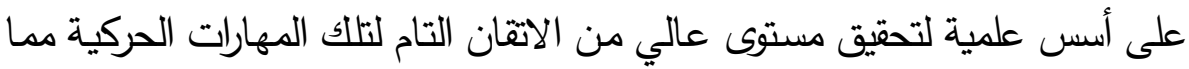
يسهم في الوصول لأعلى المستويات الرياضية.

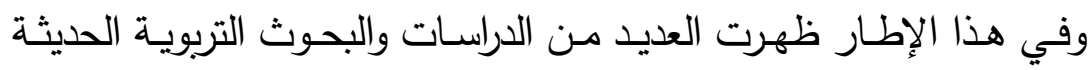

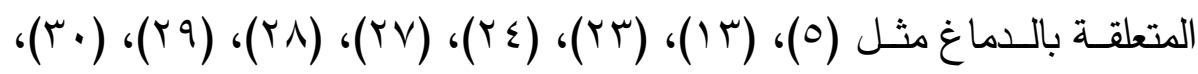

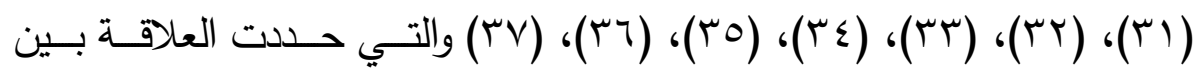


تركيب الدماغ والتعلم، كما بدأت هذه الأبحاث تثير الكثير من التساؤلات حول

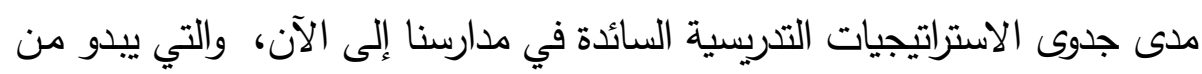

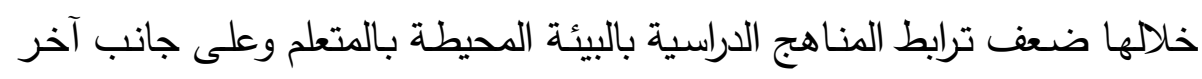
يقوم المعلم بتوصيل المعلومات بصورة تلقينيه، إضافة إلى اعتماد عملية التقويم على قياس كمية المعلومات التي خزنها المتعلم وأعاد استرجاعها.

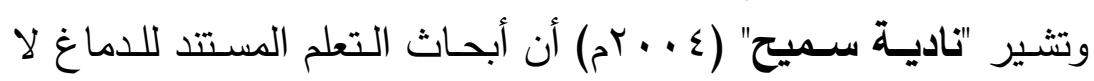

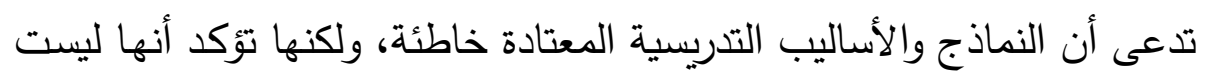

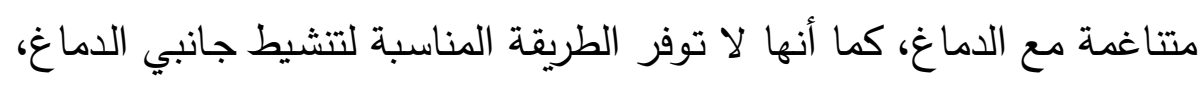

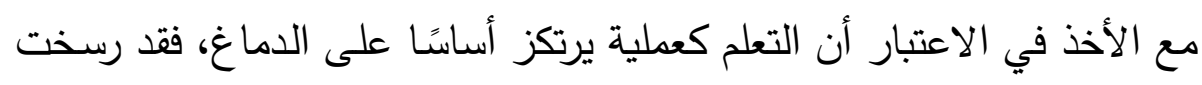

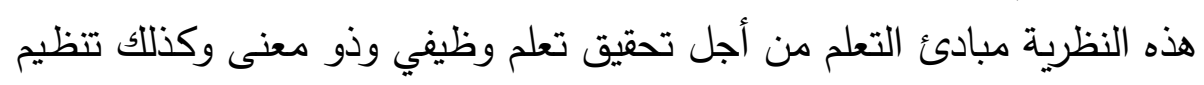

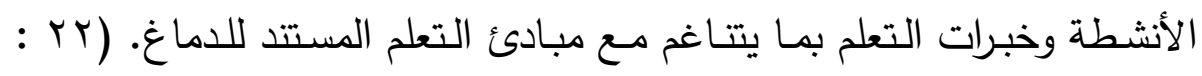
(o.

وتمثل نظريـة التعلم المستتد للدماغ منهجًا للتعليم والتعلم يعتمد علي

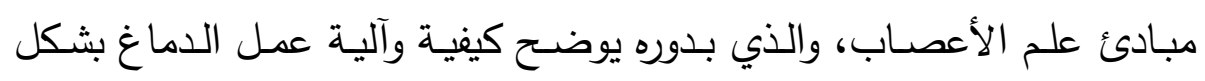
طبيعي، وتستند تلك النظرية إلى تركيب ووظائف الدماغ باعتبار أن الدماغ فيه لأنيه

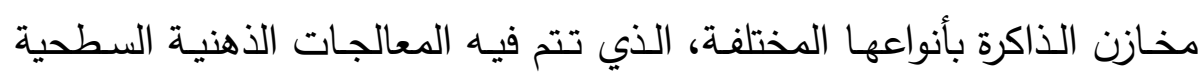

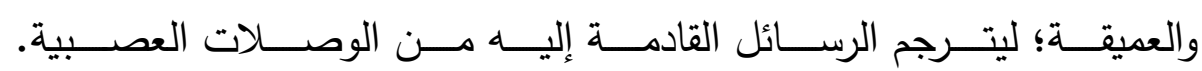
( $r V: Y V)$

وتري ليزلي هارت (Leslie Hart) أن مصطلح التعلم المتناغم مع الدماغ يقصد بـه التعليم المصمم لتكييف المواقف الدرسية (Brain- Compatible)

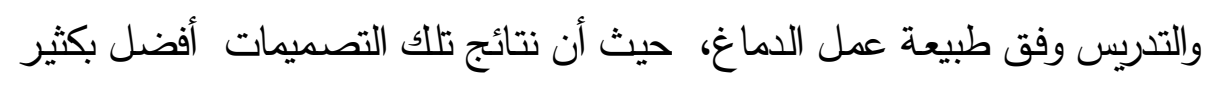

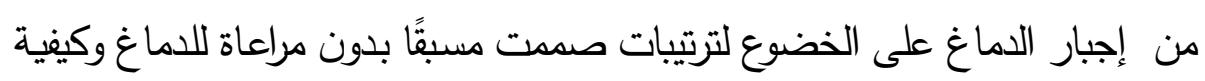

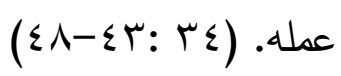


ويؤكد "بيوكـو" (Bucko, 1997) علي أهميـة نتائج أبحاث التعلم

المستند للدماغ، ومهارات التنكير ، وتطبيقات نظريات التعلم في تصميم المواقف

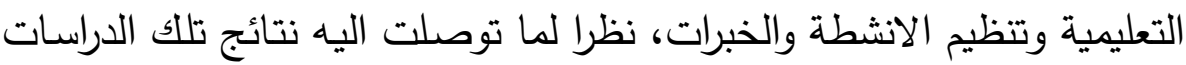

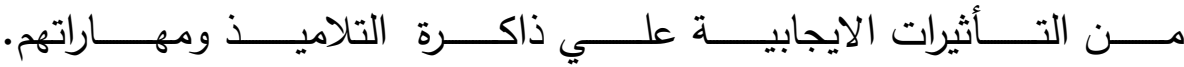
$(\leqslant r: r q)$

ويثير منير البعلبكي (T + . Tم) إلى أن نظرية التعلم المستتد للدماغ تعتمد

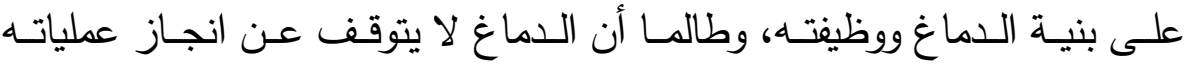
الاعتيادية، فالتعلم سوف يحدث، و كل فرد بإمكانه أن يتعلم، حيث يولد كل فرد

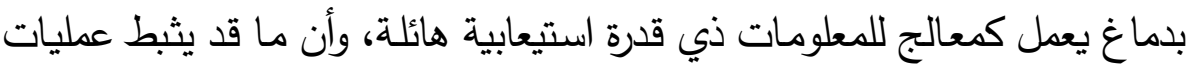

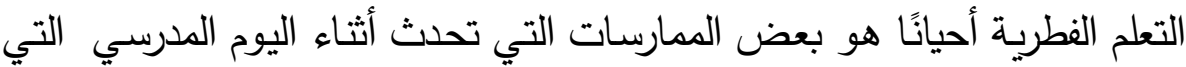

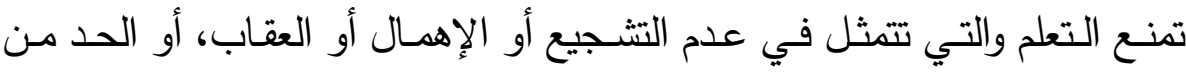

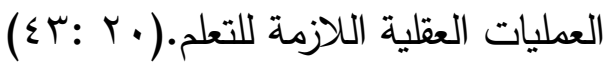

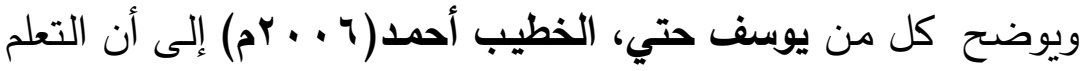

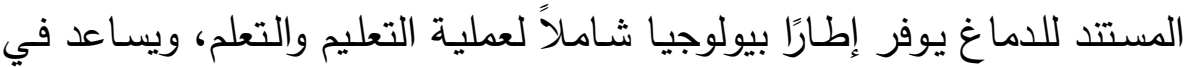
توضيح سلوكيات المتعلم، ويتضمن مزيجـا من أسـاليب تدريسية منتقاه تتيح

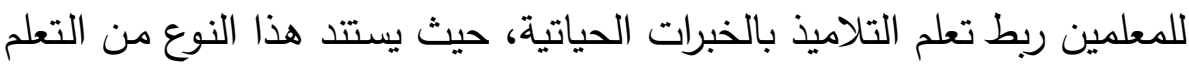

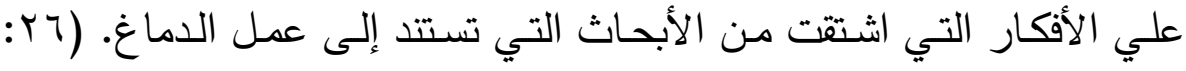
$(r$.

ولما كان التعليم المستند إلى الدماغ يركز على دور المعلم كموجـه

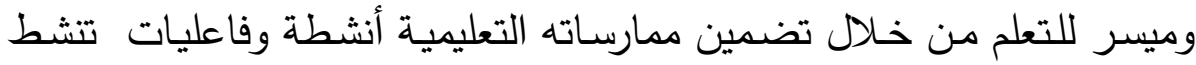
قدرات الدماغ، فانه في حاجة للمعرفة بالدماغ وكيفية عمله حتي يستطيع القيام

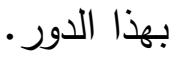

ويشسير ديفيد (David Soua, 2006) إلى أن الدماغ ينقسم إلى الى الجئ

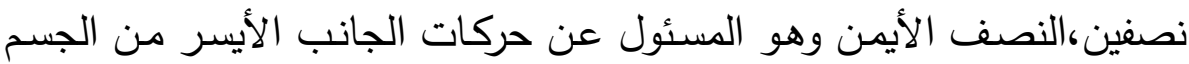


والعكس، ويرتبط نصفي الدماغ معا بواسطة حزمة من الألياف تسمى "الجسم الجاسيء" تمكن من الاتصال بين جانبي الدماغ، وتختلف خصائص كل جانب عن الجانب الآخر بحيث يكمل كل منهمـا الآخر بطريقـة متناسقة، ويتميز الجانب الأيسر بأنه تحليلي ويعالج المعلومات من خلال ربط الأجزاء بالكل كما

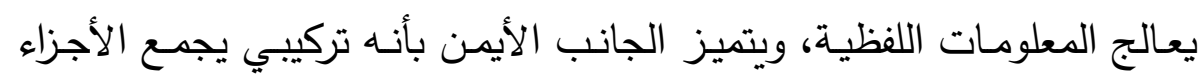
لتكوين كليات جديدة ويعالج المعلومات بالتوازي، كما يتعرف على العلاقة بين

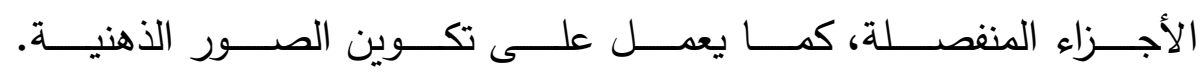

(1) (1): (1)

ويري كين (Caine, 1997) أن التعلم المستتد للدماغ هو تطبيق مجموعـة من المبادئ التي تمثل الفهم البشري لكيفيـة عمل الدماغ في سياق التعليم، حيث تدور فكرة التعلم المستتد للدماغ حول فعالية التعلم التي تكون متوافقة مع الطريقة التي يتعلم بها الدماغ، حيث أن المبدأ الرئيس للتعلم المستند

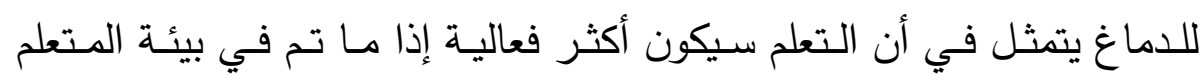

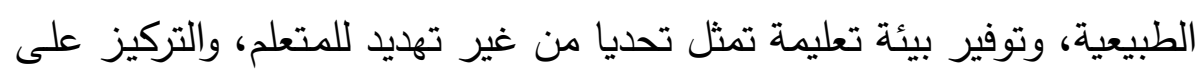
الكيفية التي يتعلم بها الدماغ، وتوفير تعلم ذا معنى من خلال استخدام الدماغ. $(\vee q: r \cdot)$

ويلخص وليم عبيد، عزو عفانـه (r . . r م) خصائص التعلم المستند

إلى الدماغ في اعتمـاده على الخبـرات البيئية والتجـارب العملية، وأن الخلايـا

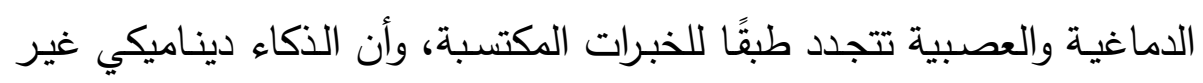

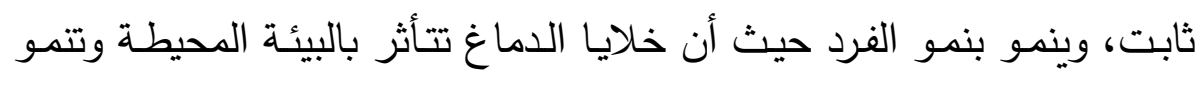

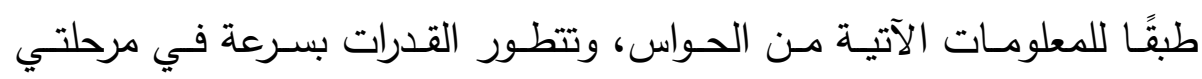
الطفولة والمراهقة.(0 ب: 1 ( )

ويؤكد كل من ديـلا وهـارت وتومـاس ( Della, Hart, Thomas,

1986) على أن أهم مبادئ التعلم المستند للدماغ تتمثل في توفير بيئة تعليمية وئوماسية 
خالية من التهديد وتزويد الموقف التعليمي بكمية أكبر من المدخلات واستخدام مهارات الاتصـال الفعـال، وإتاحـة الفرصـة للمتعلمين للقيـام بمعالجـات متعددة للمعلومـات، وربـط التعلـيم بـالواقع، وتـوفير فـرص التطبيـق واحتـرام التفكيـر

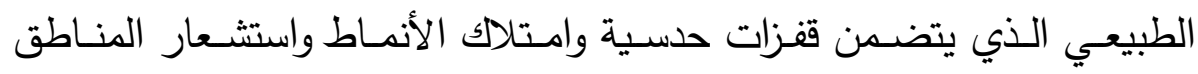

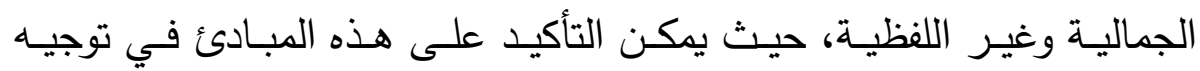

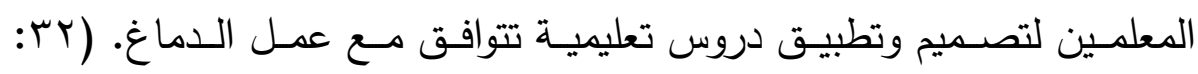
$(1 \leq \wedge-1 \leq r$

ولما كانت المهارات الأساسية في كرة اليد تتميز بالتنوع والتعدد وتزخر

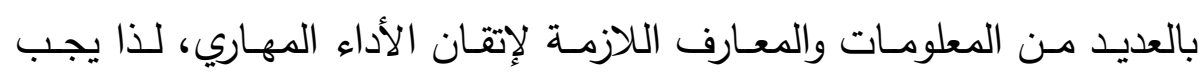
البحث عن أفضل السبل العلمية لتعليم تلك المهارات ويشـير محمد توفيـق الـوليلي (1 + . rم) أن المهارات الأساسـية (الدفاعيـة

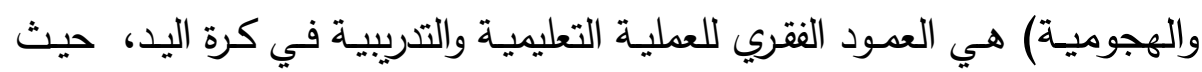

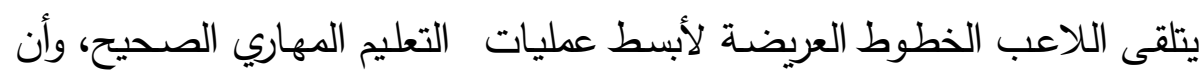

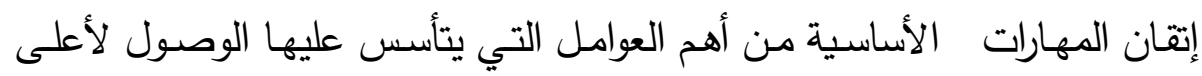

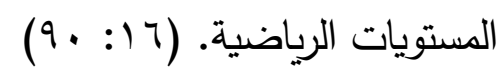

ويرى"منيـر جرجس"(ع + rم) أن المهارات الأساسية في كرة اليد

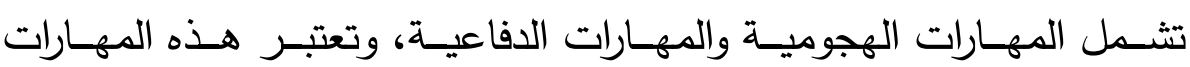
بتـدرياتها التطبيقيـة بمثابـة العدـود الفقري للعبـة كـرة اليـد، بالإضـافة إلى هـ الجانب البدني والخططي والجوانب النفسية والإعداد الذهني ( (ب: م0). ومن خلال عمل الباحث في تدريس مقرر كرة اليد لطلاب شعبة التدريس

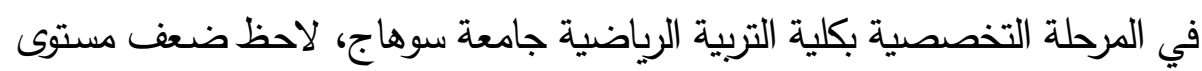

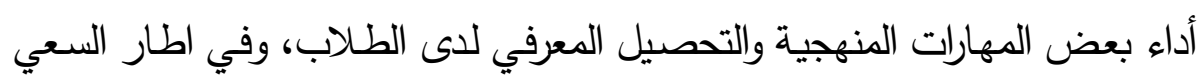
الي الاستفادة مـن نتائج الدراسـات والبحوث العلميـة المرتبطـة بعمل الدماغ وكيفية التعلم وتوظيفها في مجال تعليم كرة اليد للوصول من خلالها الي تطوير أسـاليب 
التتريس وتصميم الخبرات والانشطة التعليمية بما يتاسب مـع عمل الدماغ البشري وتـوفير بيئة تعليميـة تسـاعد علي عمليـة التعليم والتعلم لتحقيق اقصـي اسـتفادة للطلاب.

فقد اعتمد البحث الحالي علي مبادئ التعلم المستد للدماغ التي ذكرها كين وكين (Caine \& Caine, 1999)(Y9) في تصميم البرنامج التعليمي باستخدام

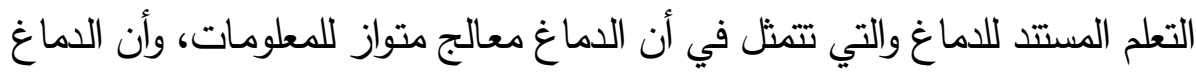
يفهم الكليات والجزئيات، وأن كل دماغ فريد، وتوظيف الحالة الفسيولوجية أثناء التعلم

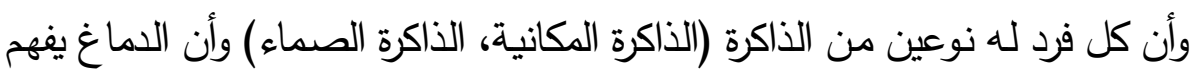
بشكل أكبر عندما تكون المهارات في الذاكرة المكانية، والبحث عن المعنى يتم بشكل فطري، والبحث عن المعنى يحدث من خلال أنماط متعددة، الانفعالات تشكل تلك الأنماطوالتعلم يتطلب الانتباه والإدرالك المحيطي، ويتطلب التعلم المعالجات الواعية وغير الواعية، والتعلم يعزز بالتحدي والتتافس ويكف بالتهديد.

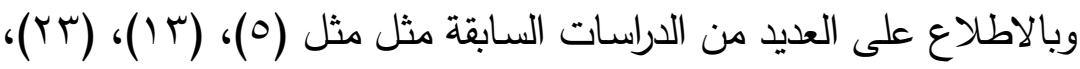

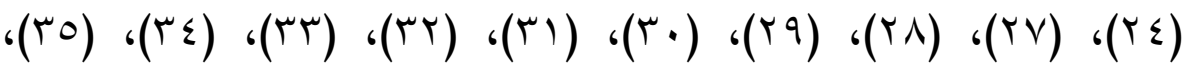
(T)، (rV) والتي أكدت على أن البرامج التعليميـة المبنيـة على التعلم المستتد للـماغاغ كانـت أفضـل مـن البـرامج التقليديـة المطبقـة في تتميـة التحصـيل والتذكر والدافعيـة ومظاهر مختلفة من التفكير وتتميـة المهارات الادائية والاجتماعية، لذا كانت من الضرورة الأخذ بها ومراعاة تصميم البرامج التعليمية وتشكيل المواقف مه التعليمية المتفقة مع عمل الدماغ. ومن خلال الدراسات السابقة التي أمكن التوصل إليها تبين ندرة الدراسات في مجال تعليم مهارات كرة اليد على - حد علم الباحث- التي اعتمدت علي نظريـة التعلم المستتد للدماغ وربما يعود ذلك إلى حداثة هذا الموضوع، وهذا مـا دفع الباحث للقيام بالبحث الحالي في محاولة للتعرف علي أثر برنـامج تعليمي باستخدام التعلم المستتد للدماغ على أداء بعض المهارات (الدفاعيـة والهجوميـة) 
9 r.

ومسـتوى التحصيل المعرفي في كرة اليـد لطـلاب كليـة التربيـة الرياضية جامعـة

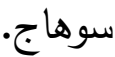

أهمية البحث: أنماج:

تتمثل أهمية البحث الحالي في الاتي:

ا - تقديم دليـل علمي على فعاليـة التعلم المسـتـد للـدماغ في تتميـة الأداء

ومستوى التحصيل المعرفي لبعض مهارات كرة اليد

r- تقديم نموذج تطبيقي لكيفية تعليم المهارات الأساسية في كرة اليد طبقا لمبادئ

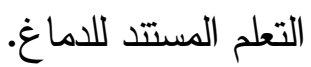

ب- قد يساعد البحث الحالي في بناء برامج مماتلة لتدريس الألعاب الرياضية

الأخرى.

ع- قد يساعد هذا البحث مخططي مناهج التربية الرياضية في ادماج مبادئ

التعلم المستند للدماغ في أنشطة مناهج التربية الرياضية.

هدف البحث:

يهدف البحث الحسالي إلى التعرف على أثر استخدام برنـامج تعليمي

باستخدام التعلم المستند للدماغ على أداء بعض المهارات (الدفاعية والهجومية)

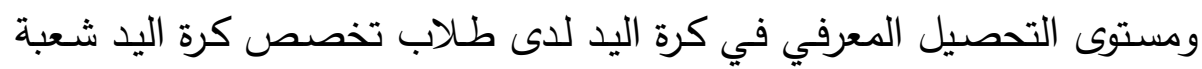
التدريس بكلية التربية الرياضية - جامعة سوهاج. فروض البحث:

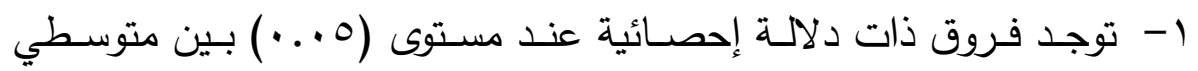
درجـات القياسـين القبلي والبعـدي للمجموعـة التجربيـة في في أداء مهارات

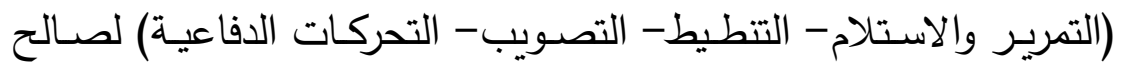
القياس البعدي.

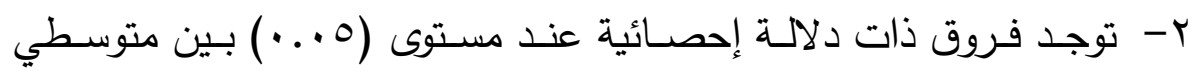

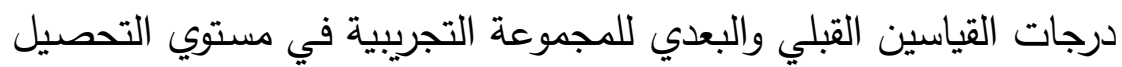
المعرفي لصالح القياس البعدي. 
المصطلحات الواردة بالبحث:

- التعلم المستتد للاماغ:

هو عملية التعلم التي تحدث اعتمادا علي بنية المـخ ووظيفته من خلال

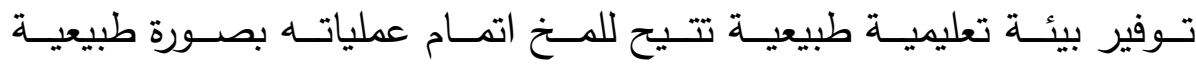

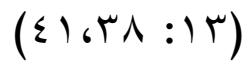

إجراءات الاراسة:

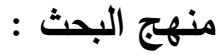

استخدم الباحث المنهج التجربي (التصميم التجريبي لمجموعة واحدة)

باستخدام القياس القبلي والبعدي للمجموعة التجريبية وعددها ـ ب طالب.

مجتمع البحث:

يمثل مجتمع هذا البحث جميع طـلاب تخصص كرة اليد (ذكور) شـعبة

التربس بكلية التربية الرياضية جامعة سوهاج وعددهم · . 1 طالب في العام الجامعي

$\cdot r \cdot r \cdot-r \cdot 19$

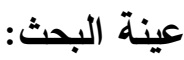

تم اختيار عينة البحث بالطريقة العدية العشوائية من بين طلاب مجتمع

$$
\text { البحث حيث بلغت عدد ( • الية) طالب. }
$$

قام الباحث بإجراء توصيف لعينة البحث في متغيرات (السن، الطول، الوزن) والجدول التالي يوضح نلل :

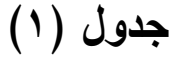

\begin{tabular}{|c|c|c|c|c|c|c|c|}
\hline الدلالة & 11:نمغاملح & $\begin{array}{l}\text { الإلتواء } 1 \text { اء } \\
\end{array}$ & الالنعياري & المستوسيم & القياسدة وحة & المتغغيرات & \\
\hline غير دال & $.71-$ & or. & . A . & YI.YA & سنة & السن & 1 \\
\hline غير دال & $\because r \cdot-$ & .r. & 0.91 & IVV.IV & سم & الطول & $r$ \\
\hline غير دال & $. r q-$ & $\ldots 0$ & $\varepsilon .0 \leqslant$ & $V 9.9 v$ & كجم & الوزن & $r$ \\
\hline
\end{tabular}

المتوبط الحسابي والإنحراف المعياري ومعامل الإلتواء والتفلطح في (السن،

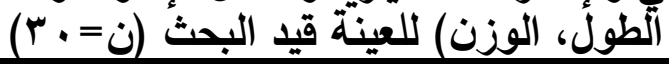

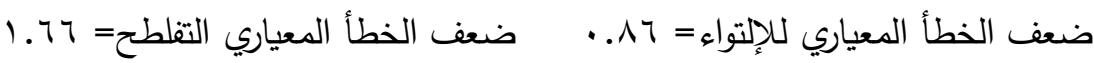




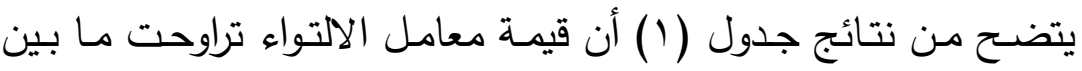

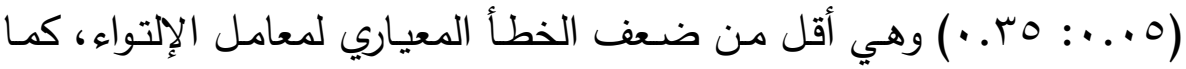

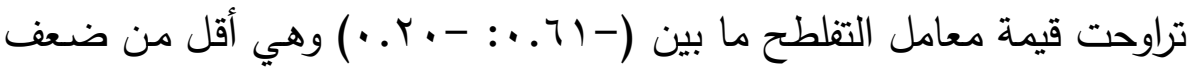

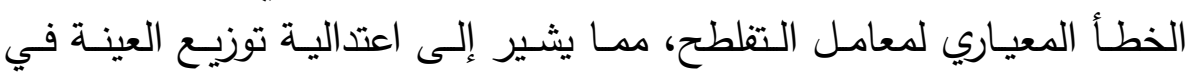
المتغيرات قيد البحث (السن، الطول، الوزني). أدوات جمع البيانات: ا - تحليل المحتوي

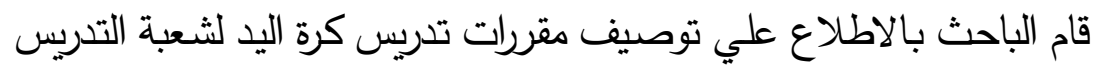

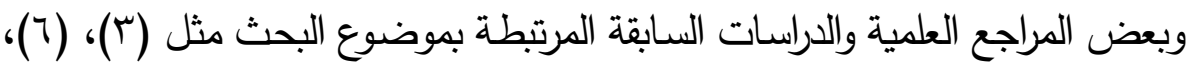

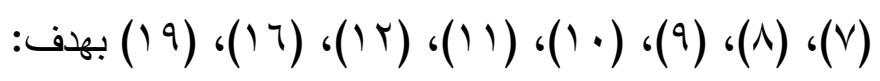

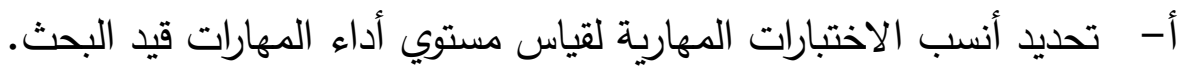
ب- تصميم الاختبار المعرفي في كرة اليد.

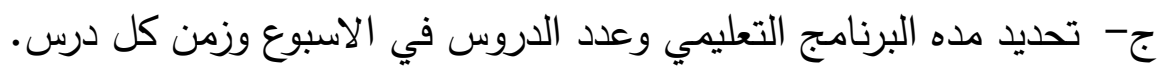
r - استمارات استطلاع آراء الساده الخبراء

استخدم الباحث استمارات استطلاع رأي السـاده الخبراء وعددهم (1) (1)

$$
\text { ملحق (1) بهدف: }
$$

أ. تحديد محاور الاختبار المعرفي في كرة اليد والاهمية النسبية لكل محور . تحد.

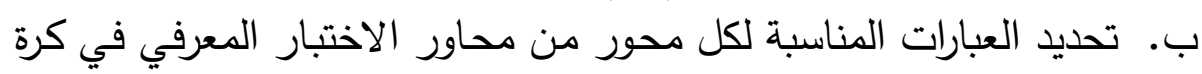
اليد.

$$
\text { ج- تحديد انسب الاختبارات المهارية. }
$$

قام الباحث بالاطلاع علي الدراسـات السـابقة والمراجع العلمية المتخصصـة

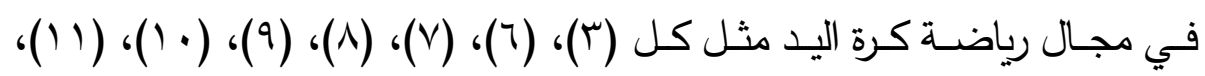
( ( ))، (7 ()، (9 ( ) وذلك لتحديد الاختبارات التي تقيس الأداء المهارى للمهارات قيد البحث ووضـعهم فى استمارة استطلاع رأى الخبـراء لتحديد أنسب الاختبـارات المهارية لقياس المهارات (قيد البحث) والمناسبة لطلاب الفرقة الثالثة شعبة التدريس 
بكلية التربية الرياضية - جامعة سوهاج ملحق (Y)، وتم حساب النسبة المئوية لهذه الآراء، وهذا ما يوضحه جدول(Y).

\section{جدول (r)}

أنسب الاختبارات المهارية للمهارات الهجومية والدفاعية (قيد البحث)

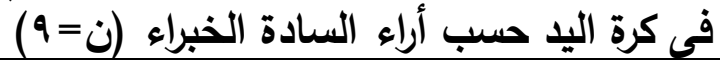

\begin{tabular}{|c|c|c|c|c|}
\hline المئوية (\%) & التكرار & القياسة وحدة & الاضنتبارات المهارية & م \\
\hline$P V, V V$ & $\mathrm{~V}$ & عدد & التمرير والاستلام على حائط(·rث). & 1 \\
\hline YY,YY & r & عدد & التوافق وسرعة التمرير لمدة ·rث. & $r$ \\
\hline- & - & عدد & رمي الكرة لأبعد مسافة مع الثبات. & $r$ \\
\hline 11,11 & 1 & عدد & التبطيط المستمر في خط مستقيم لمسـافة & $\varepsilon$ \\
\hline 11,11 & 1 & عدد & (ذهابا). & 0 \\
\hline$\checkmark V, V \vee$ & V & عدد & 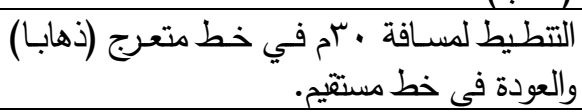 & 7 \\
\hline$\checkmark V, V V$ & V & عدد & 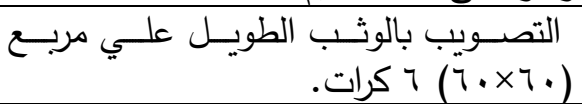 & V \\
\hline 11,11 & 1 & عدد & التصويب على المربعات المتداخلة. & $\Lambda$ \\
\hline 11,11 & 1 & عدد & والتصويب من الثبات • ( كرات من خط ال & 9 \\
\hline$\wedge \wedge, \wedge \wedge$ & $\wedge$ & عدد & التحركات الدفاعية المتتوعة. & 1. \\
\hline 11,11 & 1 & عدد & التحركات الدفاعية للأمام والخلف. & 11 \\
\hline- & - & عدد & الخاطفـار التحركات الدفاعيـة لتغطيـة الهجوم & IT \\
\hline
\end{tabular}

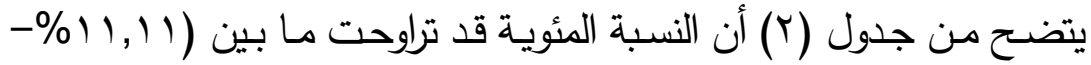

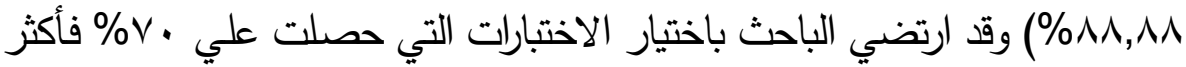
وبنلك تم اختيار اختبارات (التمرير والاستلام علي حائط ( •"ث)، والتطيط لمسافة • آم في خط متعرج (ذهابا) والعودة في خط مستقيم، والتصـويب بالوثب الطويل علي مربع (• • × • (7) 7 كرات، والتحركات الدفاعية المتتوعة) ملحق (T). ع - اختبار التحصيلي المعرفي للمهارات قيد البحث (تصميم الباحث)

\section{مجلة أسيوط لعلوم وفنـون التربية الرياضية}


لإعداد الاختبار التحصيلي في المعارف المتعلقة بالمهارات قيد البحث

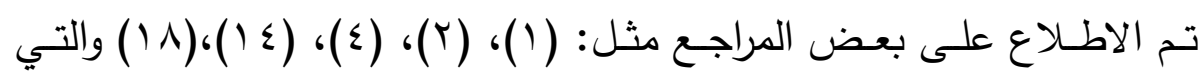

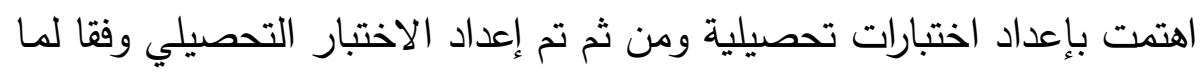
يلي

- - تحديد المحاور الرئيسية للاختبار المعرفي في ضوء أهداف مقرر تدريس كرة اليد بعد عرضها على السادة المحكمين وهي: تاني تاريخ كرة اليد. النواحي القانونية المرتبطة بالمهارات قيد البحث.

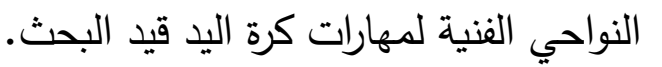

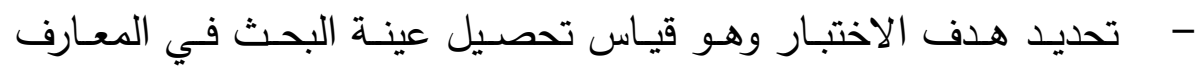

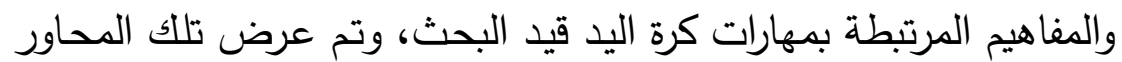
علي السادة الخبراء وجدول (ب) التالي يوضسح نسبة موافقة السادة الخبراء

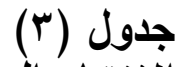
علي محاور الاختبار تحديد الأهمية النسبية لمحاور الاختبار المعرفي وفقا لآراء السادة الخبراء ( $11=\dot{0})$

\begin{tabular}{|c|c|c|c|c|}
\hline المئوبة & 1اتنكرارات & النسبيةية & مهاور الاذتبار & م \\
\hline$\% \wedge 1 . \wedge 1$ & 9 & $\% 1$. & طبيعة وتاربخ كرة اليد & 1 \\
\hline$\% 1 \ldots$ & 11 & $\% 4$. & مهارات كرة اليد & $r$ \\
\hline$\% 9 . .91$ & 1. & $\%$ \%. & النواحي القانونية & $r$ \\
\hline
\end{tabular}

يتضـح مـن جدول (r) أن نسـبة موافقـة السـادة الخبـراء على محساور

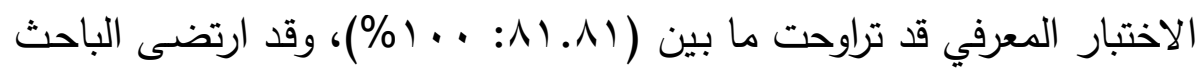

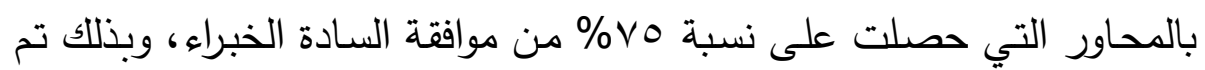

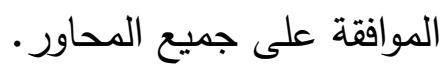
- صياغة مفردات الاختبار المعرفي: 


\section{0}

قـام الباحث بصـياغة مفردات الاختبـار المعرفي وبلـغ عددها (م) (م) مفردة، تمثلت في نوعان من الأسئلة (الصواب والخطأ والاختيار من متعدد) وقد روعي في هذه المغردات ما يلي:

أن تقيس مستوى التحصيل المعرفي في الثلاث محاور الرئيسية. أن تكون مناسبة لسن ومستوى العينة. أن تتسم بالشمول والوضوح، وعدم احتمال اللفظ لأكثر من مدلول، وتتسم بالسهولة اللغوية. - تحديد المستويات المعرفية للاختبار المعرفي في كرة اليد:

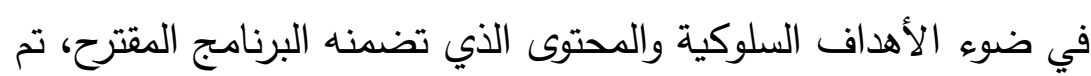

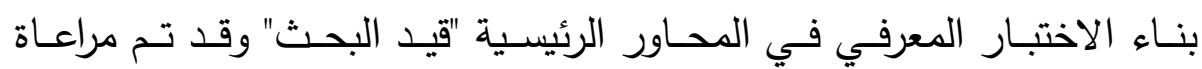
المستويات المعرفية وفقا لتصنيف بلوم bloom للأهداف في المجال المعرفي فقد تضمن الاختبار المعرفي الثلاث مستويات الأولي وهم (التذكر - الفهمالتطبيق) - إعداد الصورة المبدئية لاختبار التحصيل المعرفي في كرة اليد وعرضهها : على المحكمين

تم إعداد الصورة المبدئية للاختبار ، بحيث ان تكون المفردات متنوعة

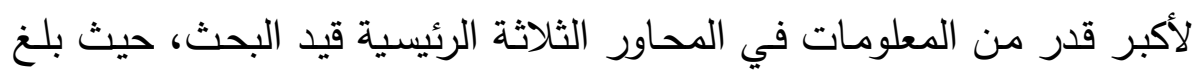

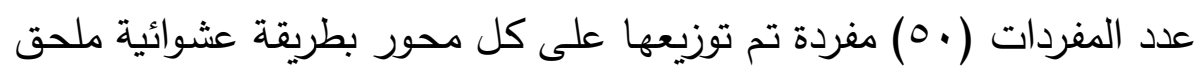

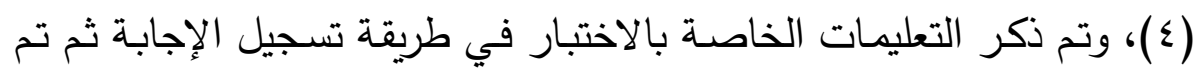
عرض هذه الصورة المبدئية للاختبار على عدد (1) خبير في مجال المناهج

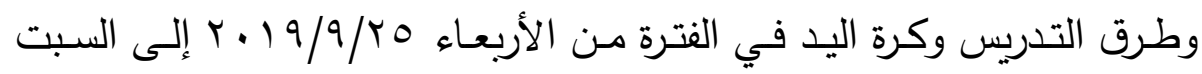

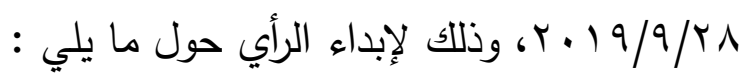

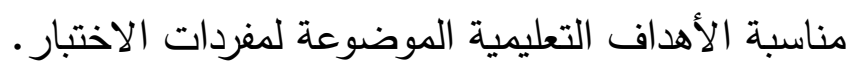
الصياغة اللغوية السليمة والدقة العلمية لمفردات الاختبار • 
شـول مفردات الاختبار لكافـة المعلومـات المتضـمنة بالبرنـامج التعليمي

المقترح.

مناسبة الاختبار لمستوى العينة.

$$
\text { وضوح تعليمات الاختبار }
$$

واستخدم الباحث النسـبة المئويـة لآراء السـادة الخبراء بهدف اسـتخلاص المغردات الأكثر مناسبة لكل محور وجدول (ع) يوضح ذلك. جدول (ع الخدون

النسبة المئوية لموافقة السادة الخبراء على مفردات الاختبار المعرفي

$$
\text { (1 } 11=0)
$$

\begin{tabular}{|c|c|c|c|c|c|}
\hline المئوبـة & المفردة رقم & النئوية & المفردة رقم & النئوبة & المفردة رقم \\
\hline $9 . .91$ & rq & $9 . .91$ & $r$. & $9 . .91$ & 1 \\
\hline $1 \ldots$ & $\varepsilon$. & NI.Ar & YI & $1 \ldots$ & r \\
\hline Al.AY & «1 & $9 . .91$ & r & Al.Ar & $r$ \\
\hline $9 . .91$ & $\sum r$ & $9 . .91$ & rT & $1 \ldots$ & $\varepsilon$ \\
\hline $1 \ldots$ & $\varepsilon r$ & $1 \ldots$ & $Y \varepsilon$ & NI.Ar & 0 \\
\hline Al.Ar & $\varepsilon \varepsilon$ & NI.AK & ro & NI.AY & 7 \\
\hline $9 . .91$ & $\leqslant 0$ & NI.AY & T & $0 \leqslant .00$ & $* \gamma$ \\
\hline $9 . .91$ & $\leqslant 7$ & NI.Ar & rV & ᄉl.Ar & $\wedge$ \\
\hline $1 \ldots$ & $\sum V$ & $1 \ldots$ & rA & $1 \ldots$ & 9 \\
\hline Ar & $\leqslant \wedge$ & $9 . .91$ & rq & ᄉl.Ar & 1. \\
\hline $9 . .91$ & $\leqslant 9$ & $1 \ldots$ & r. & VY.VT & *11 \\
\hline \multirow[t]{8}{*}{$9 . .91$} & 0 . & 11.11 & * & NI.Ar & 14 \\
\hline & & $9 . .91$ & Tr & $1 \ldots$ & 15 \\
\hline & & ع & rTH & $9 . .91$ & $1 \varepsilon$ \\
\hline & & $1 \ldots$ & ए乏 & $1 \ldots$ & 10 \\
\hline & & $9 . .91$ & ro & NI.Ar & 17 \\
\hline & & $1 \ldots$ & r & $1 \ldots$ & IV \\
\hline & & $9 . .91$ & rV & $9 . .91$ & 11 \\
\hline & & NI.Ar & rᄉ & $1 \ldots$ & 19 \\
\hline
\end{tabular}

* تحذف *

يتضح من جدول (ع) ما يلى : 
- تراوحت النسب المئويـة للمفردات التي تمـ الموافقـة عليها مـن السـادة

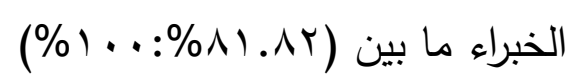

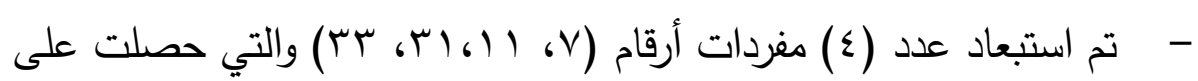

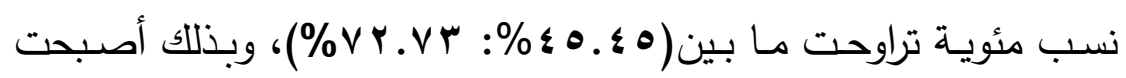

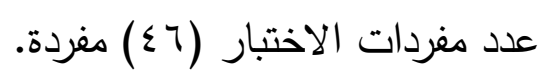

- معامل السهولة والصعوبة والتمييز لمفردات الاختبار:

بعد عرض الاختبار المعرفي على السادة الخبراءهتم بتطبيق الاختبار المعرفي في صورته المبدئية على عينة عددها ( • (ب) طالب من طلاب الفرقة الرابعة شعبة التدري الذين درسوا مقرر تدريس كرة اليد في العام السابق بكلية التربية الرياضية جامعة سوهاج خلال الفترة من الثلاثاء / / • 1 إلى الاربعاء

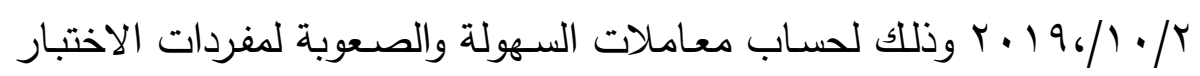
باستخدام المعادلة التالية:

عدد الأفراد الذين أجابوا إجابة صحيحة على كل مفردة

عدد الأفراد الكلي

والعلاقة بين معامل السـهولة ومعامل الصعوبة علاقة عكسية، بمعنى

أن مجموعهم يساوي الواحد الصحيح كالتالي:

معامل السهولة = (- معامل الصعوبة

معامل الصعوبة = 1 - معامل السهولة

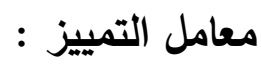

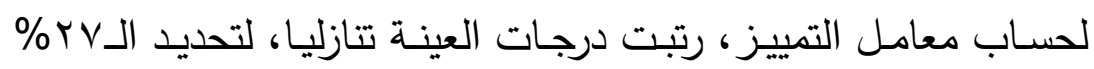
العليا وكذلك الـrV\% السفلى، بهدف تحديد معامل التميز لكل عبارة باستخدام المعادلة التالية: - n

عدد الإجابات الصحيحة في المجموعة العليا - عدد الإجابات الصحيحة في المجموعة الانيا 
عدد المبحوثين في إحد المجموعتين

معامل التمييز=

وقد تم قبول المفردات التي يتوفر فيها الشرطين التاليين:

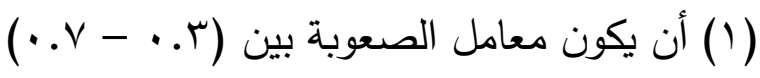

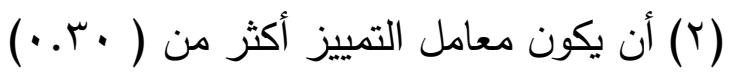

ويوضح جدول (0) معاملات الصعوبة والتمييز لمفردات الاختبار المعرفي.

جدول (0)

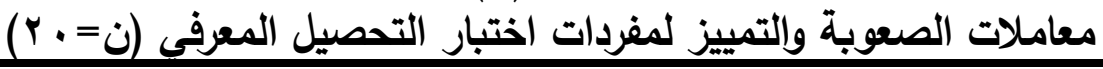

\begin{tabular}{|c|c|c|c|c|c|c|c|c|}
\hline التمعامل & المعامبـة معال & المفردة رقم & التمعامل & الصعوبـة معامل & المفردة رقم & التمبيلزمل & المعوبـة معامل & المفردة رقم \\
\hline. $.0 \mathrm{~V}$ & 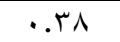 & זr & $. .1 \leqslant$ &..$\wedge \varepsilon$ & $* \mid V$ & $.0 \mathrm{~V}$ & .7. & 1 \\
\hline דז'. & .77 & $r \varepsilon$ &.$\wedge 7$ & $\because \leqslant \wedge$ & 11 & .0 &.$v$. & $r$ \\
\hline. ro $_{0}$ & $.1 r$ & * * & דו . & .77 & 19 & דו . & .07 & $r$ \\
\hline.$v 1$ &.$v \cdot$ & ד & $.0 \mathrm{~V}$ &..$T Y$ & $r$. & r &. .71 & $\varepsilon$ \\
\hline.$\leqslant \Gamma$ & $.7 \varepsilon$ & rV & 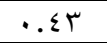 &.$\Gamma \varepsilon$ & rI &.$v^{\prime}$ & $.0 Y$ & 0 \\
\hline..$\vee 9$ & .07 & एᄉ &.$\wedge 7$ &. $.7 Y$ & Yr & $\therefore \vee 9$ & .01 & 7 \\
\hline דו.. &..$\leqslant \wedge$ & rq & $\ldots V$ &.$\vee \vee \wedge$ & $* r r$ & $.7 \varepsilon$ & $.7 \leqslant$ & $\mathrm{~V}$ \\
\hline .0 &..$\leqslant \leqslant$ & $\varepsilon$. & $.7 \varepsilon$ & . . $\{r$ & $r \varepsilon$ &.$v 9$ & .71 & $\Lambda$ \\
\hline $.7 \varepsilon$ & .0 & $\varepsilon 1$ & $.0 \mathrm{~V}$ & .07 & ro & $.0 \mathrm{~V}$ & .77 & 9 \\
\hline$\therefore \vee 9$ &.$r \varepsilon$ & $\sum r$ &..$\times 1$ &.$\leqslant 7$ & $r 7$ &..$r q$ & $\cdot r$. & $* 1$. \\
\hline $.0 \mathrm{~V}$ & .07 & $\varepsilon r$ & 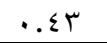 &.$\Gamma \varepsilon$ & TV & $.7 \leqslant$ &. .71 & 11 \\
\hline דו & 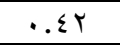 & $\varepsilon \varepsilon$ & $\because \vee 99$ & ד & rA & .0 & .77 & Ir \\
\hline $.1 \times 9$ & .0 & $\leq 0$ & .94 & $.0 \leqslant$ & rq & . & .07 & $1 \pi$ \\
\hline \multirow[t]{3}{*}{$.7 \leqslant$} & .07 & $\sum 7$ & $\because \vee \vee 9$ & $\cdot . \vee \cdot$ & $r$. &.$v^{\prime}$ & .7. & $1 \varepsilon$ \\
\hline & & &.$\leqslant r$ &. $.7 r$ & M & .94 & $.7 \varepsilon$ & 10 \\
\hline & & & $\ldots V$ &.$\wedge$. & *r &.$r^{\prime}$ & $\because \vee \wedge$ & $* 17$ \\
\hline
\end{tabular}

يتضح من جدول (0) أنه قد تم استبعاد عدد (T) عبارات لم يتوفر فيهم

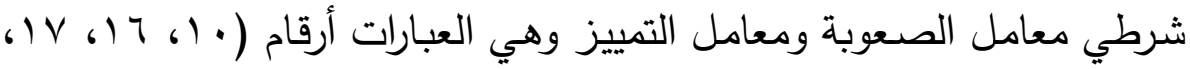
سץ، بr، 0ب)، وبذلك اصبح عدد مفردات الاختبار ( • ع) مفردة تراوح فيها

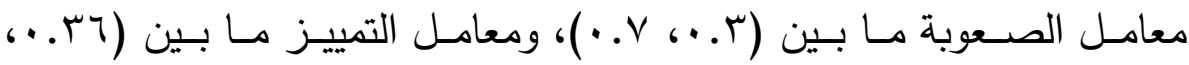


سو . •)، وبنـاء عليـه فإنـه يمكن اسـتخدام الاختبـار كـأداة لتقيـيم التحصـيل

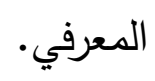

- تقديرات الارجات وطريقة التصحيح :

تعطى درجـة واحدة لكل إجابـة صـحيحة مـن عبـارات الصـواب والخطـأ

والاختيـار مـن متعدد، وصـفر لكل إجابـة خاطئة، وبالتـالي تكون الدرجـة الكليـة لاختبار التحصيل المعرفي من ( • ع) درجة، وقد تم إعداد مفتاح التصحيح لتسهيل عملية التصحيح وبذلك تم التوصل للصورة النهائية للاختبار المعرفي ملحق (0). - - تحديد زمن الاختبار: وتم تحديد زمن الاختبار وفقا للمعادلة التالية: الزمن الذي استغرقه أول طالب + الزمن الذي استغرقه آخر طالب

زمن الاختبار

\section{r}

حيث تم تحديد زمن الاختبار (مب دقيقة).

المعاملات العلمية لاختبار التحصيل المعرفي في كرة اليد والاختبارات المهارية قيد البحث : 20

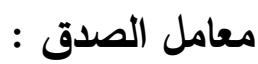

لإيجاد معامل الصدق لاختبار التحصيل المعرفي والاختبارات المهاريـة

استخدم الباحث طريقة صدق التمايز وذلك بتطبيق الاختبار على مجموعتين (مميزة- غير مميزة) من مجتمع البحث و خارج عينته الأساسية بواقع ( ( ) طلاب لكل مجموعة، المجموعة غير مميزة وهم من الطلاب الحاصلين علي تقديرات (مقبول - جيد) في مقرر كرة اليد العام السابق، المجموعة المميزة من الطلاب الحاصلين علي تقديرات (جيد جدا - ممتاز) في مقرر كرة اليد العام

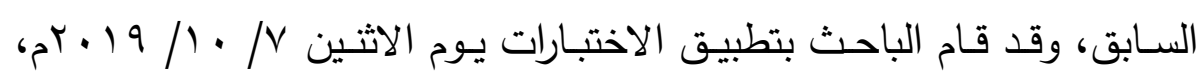
وجدول (T)، (Y) يوضح ذللك.

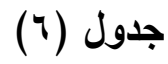


دلالة الفروق بين المجموعتين المميزة وغير المميزة في التحصيل المعرفي قيد

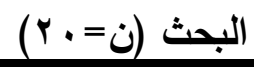

\begin{tabular}{|c|c|c|c|c|c|c|}
\hline \multirow[b]{2}{*}{ "تهمة" } & \multicolumn{2}{|c|}{ المجمو عة غير المميزة } & \multicolumn{2}{|c|}{ المجمو عة المهي.زة } & \multirow[b]{2}{*}{ والقياسـرة } & \multirow[b]{2}{*}{ المتغيرات } \\
\hline & الإلـهياري & المستوسيكي & الإلنعياريك & المتوسابي & & \\
\hline$* 11 . .7$ & 1.01 & $\varepsilon .0$. & Y.AI & r..q. & & التحصيل المعرفي \\
\hline
\end{tabular}

يتضـح مـن جدول (T) وجـود فـروق دالـة إحصــائيا بـين المجمـوعتين

المميزة وغير المميزة في التحصيل المعرفي قيد البحث حيث بلغت قيمـة (ت)

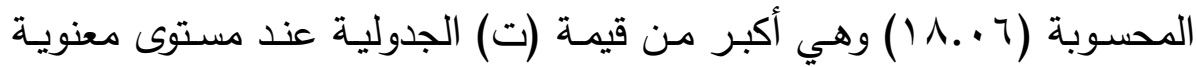
o . . • مما يدل على صدق الاختبار قيد البحث.

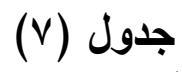

دلالة الفروق بين المجموعتين المميزة وغير المميزة في الاختبارات المهارية

\begin{tabular}{|c|c|c|c|c|c|c|}
\hline \multirow{2}{*}{ "تبهة" } & \multicolumn{2}{|c|}{ المجمو عة غير المميزة } & \multicolumn{2}{|c|}{ المجمو عة المهيزة } & \multirow{2}{*}{ القباسدة وصد } & \multirow[b]{2}{*}{ المتغغيرات } \\
\hline & المعهيارئي الإنهراف & المنتوسابيم & المعهياري الإنهرافي & المستوابير & & \\
\hline$* 1 \leq . r$. & $.1 \times 9$ & $\varepsilon . Y$. & 1.70 & IY.E. & & التمرير والاستلام \\
\hline *) $v .94$ & 1.01 & TV.E. & 1.10 & $17 \ldots$ & & التتطيط \\
\hline$* \vee . 乏 \wedge$ & . & $\cdot . \wedge$. &.$V \varepsilon$ & r.l. & & التصويب \\
\hline$* 1 . .91$ &. .99 & r.l. &.$\wedge \varepsilon$ & 7.7. & & التحركات الدفاعية \\
\hline
\end{tabular}

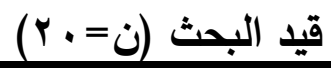

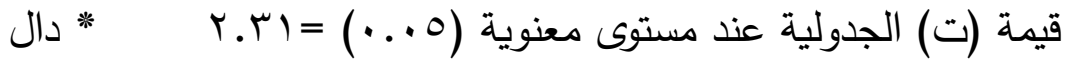

يتضـح مـن جدول (V) وجـود فروق دالـة إحصـائيا بـين المجمـوعتين

المميزة وغير المميزة في التحصيل المعرفي قيد البحث حيث تراوحت قيمة (ت)

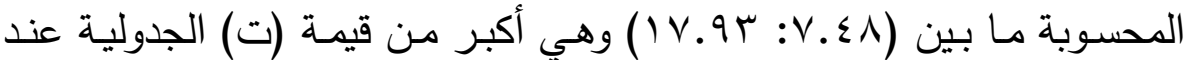
مستوى معنوية 0 . . . مما يدل على صدق الاختبارات قيد البحث. 
لإيجـاد معامل الثبات للاختبار المعرفي والاختبارات المهاريـة قيد البحث

استخدم الباحث طريقة تطبيق الاختبار وإعادة التطبيق على نفس المجموعة المميزة

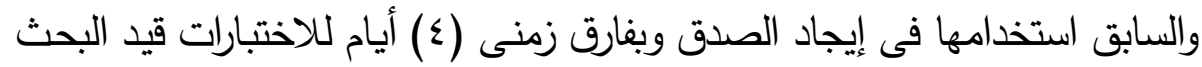

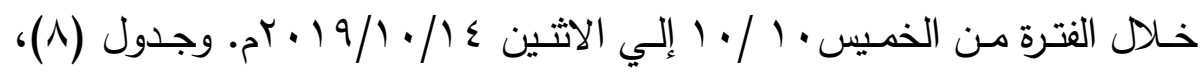

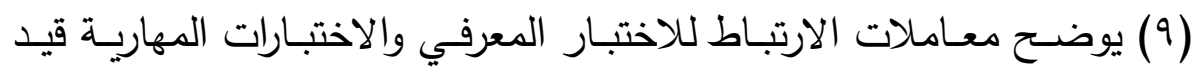

\section{جدول (^)}

معامل إرتباط بين التطبيق الأول وإعادة التطبيق في التحصيل المعرفي قيد

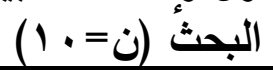

\begin{tabular}{|c|c|c|c|c|c|c|}
\hline \multirow{2}{*}{ "ريمة " } & \multicolumn{2}{|c|}{ إعادة التنطبيةق } & \multicolumn{2}{|c|}{ التطبيزو الأول } & \multirow[b]{2}{*}{ القياسرة } & \multirow[b]{2}{*}{ المتغيرات } \\
\hline & الإنـــارياف & المستوابيى & المعهياري الإنـراف & المتوسابي & & \\
\hline. .94 & $r .17$ & r.T.V. & Y.AI & r. .9. & & التحصيل المعرفي \\
\hline
\end{tabular}

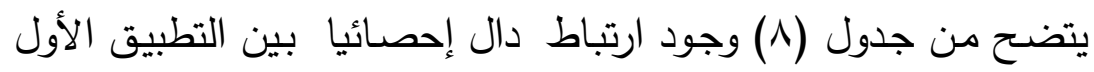

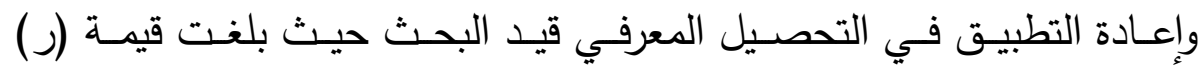

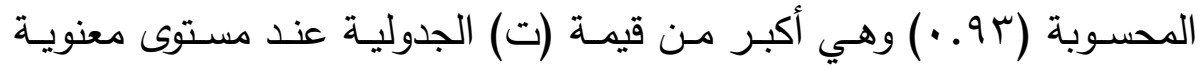

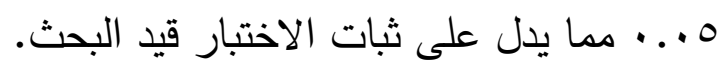

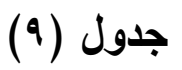

معامل إرتباط بين التطبيق الأول وإعادة التطبيق في الإختبارات المهارية قيد

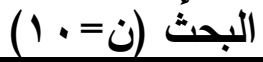

\begin{tabular}{|c|c|c|c|c|c|c|}
\hline \multirow[b]{2}{*}{ "ريمة" } & \multicolumn{2}{|c|}{ إعادة التطبيقة } & \multicolumn{2}{|c|}{ التطبيزو الأول } & \multirow[b]{2}{*}{ القياسدر } & \multirow[b]{2}{*}{ المتغغيرات } \\
\hline & 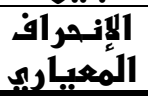 & المتوابسي & المعنياريد & المتوسابي & & \\
\hline$* .90$ & $1 . \varepsilon$. & 11.1. & $1.7 \varepsilon$ & IT.r. & & التمربر والاستلام \\
\hline$* . . \wedge 9$ & 1.77 & 19.1. & T.RT & $r . .1$. & & التنطيط \\
\hline$* .97$ &..$\wedge \varepsilon$ & $1 . \varepsilon$. &..$\leqslant \wedge$ & $1 . r$. & & التصويب \\
\hline$* . .9 V$ & $1 . \varepsilon \mu$ & T.7. & 1.17 & r.r. & & التحركات الدفاعية \\
\hline
\end{tabular}


يتضـح مـن جدول (9) وجـود فـروق دالـة إحصـائيا بـين المجمـوعتين

المميزة وغير المميزة في التحصيل المعرفي قيد البحث حيث تراوحت قيمة (ت)

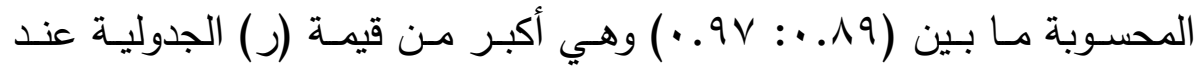
مستوى معنوية ه . . . مما يدل على ثبات الاختبارات قيد البحث.

البرنامج التعليمي المقترح : أ- - مدف البرنامج:

يهدف البرنامج المقترح الى توظيف بعض اسـاليب وطرق التدريس التي تتوافق مع مبادئ التعلم المستند الي الدماغ لتنمية مستوى التحصيل المعرفي واتقان أداء بعض مهارات كرة اليد (الهجومية- الدفاعية) لطلاب الفرقة الثالثة شعبة التتريس تخصص كرة اليد بكلية التربية الرياضية جامعة سوهاج. ب- أسس بناء البرنامج: - أن يحقق البرنامج الهدف الموضوع من أجله

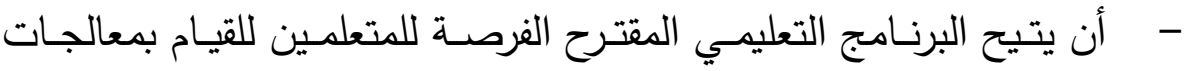
متعددة للمعلومات. - - أن يــوفر البرنــامج فـرص متعـددة لتطبيـق المهــارات وتوظيـف الحالـة الفسيولوجية أثناء التعلم باستخدام الذاكرة المكانية - - التنوع في أنشطة البرنامج بما يراعي الفروق الفردية بين المتعلمين.

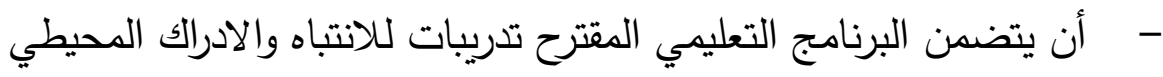

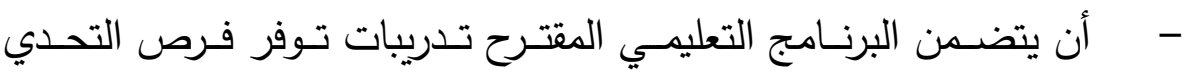
والتنافس وكف التهديد - - التـوع في طرق وأسـاليب تدريس التي تتناسـب مـع كيفية عمل الدماغ تتمثل في (حل المشكلات - الاكتشاف الحر - الاكتشاف الموجه)

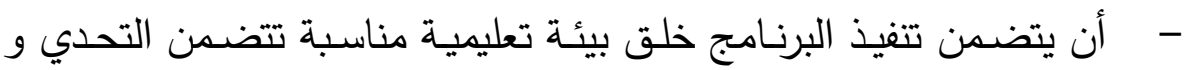
يغيب فيها عنصر التهديد. 
- - أن يتوافر عاملي الأمن والسلامة في بيئة التعلم. - أن يتميز البرنامج بالسهولة والمرونة أثناء التطبيق. ج - توصيف البرنامج التعليمي المقترح:

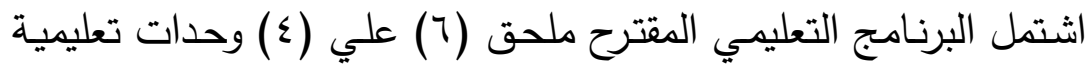

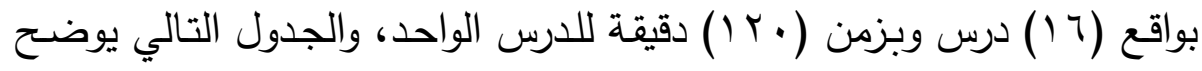
ذلك.

$$
\text { جدول (·) (1) }
$$

توصيف البرنامج التعليمي المقترح (1)

\begin{tabular}{|c|c|c|c|c|c|c|c|c|c|}
\hline 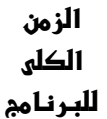 & الأسابير عدد & الدرسز & \multicolumn{4}{|c|}{ فى كل وهدة الدروس } & الومدات في & في البرنامجي & في الأسبور الدرس \\
\hline \multirow{2}{*}{$\begin{array}{l}194 . \\
\text { دقيقة }\end{array}$} & \multirow{2}{*}{ ^ أسابيع } & \multirow{2}{*}{ دقيقة $\begin{array}{l}K . \\
\text { دقية }\end{array}$} & الدفركية & التصويب & التنطيط & والاستلام & \multirow{2}{*}{ تعليمية } & \multirow{2}{*}{ درس } & \multirow{2}{*}{ ז درس } \\
\hline & & & گ دروس & ؛ دروس & دروس & $\begin{array}{c}\text { دروس } \\
\text { دوس }\end{array}$ & & & \\
\hline
\end{tabular}

قـام الباحث بتطبيق درسين مـن البرنـامج المقترح على أفراد العينـة

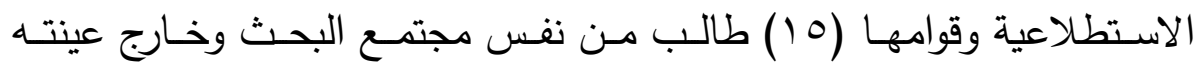

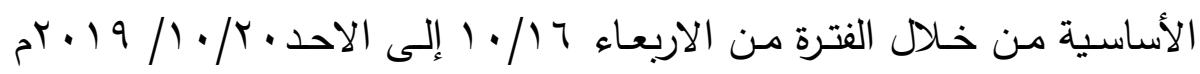
بهدف التعرف على ما يلى: مدي مناسبة اساليب وطرق التدريس وما يتضمنه

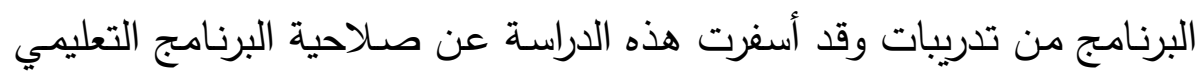
المقترح للتطبيق.

\section{تطبيق البرنامج :}

قبل البدء في تطبيق البرنامج قام الباحث بالتحقق من اعتدالية عينة

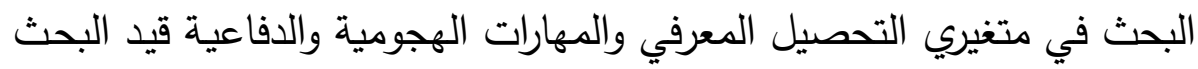
جلول (11) (11)

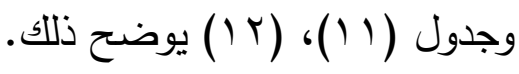
المتوسط الحسابي والانحراف المعياري ومعامل الإلتواء والتفلطح في التحصيل المعرفي للعينة قيد البحث (ن= • بـ) 


\begin{tabular}{|c|c|c|c|c|c|c|c|}
\hline الدلة11 & 1م:نهامل & الإلتنواء معاءل & المعهبارئي & المتوسيطابيم & ولقباسة & البنبناراتبة & م \\
\hline غير دال & $. Y Y-$ & $.10-$ & T.ro & $17 . . V$ & & التحصيل المعرفي & 1 \\
\hline
\end{tabular}

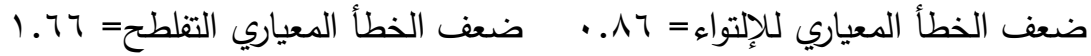
يتضح من نتائج جدول (1) أن قيمة معامل الالتواء بلغت (-0 (. (.) وهي أقل من ضنعف الخطأ المعياري لمعامل الإلتواء، كما بلغت قيمة معامل التفلطح (-r - . • ) وهي أقل من ضعف الخطأ المعياري لمعامل التفلطح، مدا يشير إلى إعتدالية توزيح العينة في التحصيل المعرفي للعينة قيد البحث.

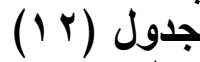

المتوسط الحسابي والإنحراف المعياري ومعامل الإلتواء والتفلطح في

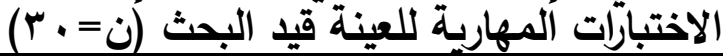

\begin{tabular}{|c|c|c|c|c|c|c|c|}
\hline الدلة11 & 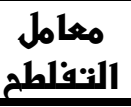 & الإلتنواء مهاء & المعهبارئي & المتنوابسي & ولقهدة وباسر & الإفتبارات & م \\
\hline غير دال & $\cdot .94-$ &.$T V$ & $1 . \leqslant 7$ & 11.94 & & التمرير والاستلام & 1 \\
\hline غير دال &. .77 & $.7 V-$ & $1 . V V$ & 19.74 & & التتطيط & r \\
\hline غير دال &..$r \varepsilon$ &. .71 &. .71 & $1 . \varepsilon r$ & & التصويب & $r$ \\
\hline غير دال & $\cdot .9 \cdot-$ & .01 & 1.. & r. r & & التحركات الدفاعية & $\varepsilon$ \\
\hline
\end{tabular}

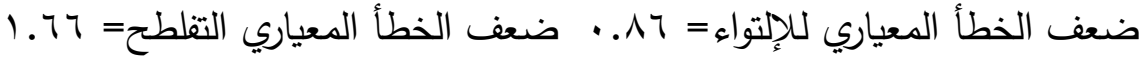
يتضـح من نتائج جدول (Y I) أن قيمـة معامل الالتواء تراوحت مـا بين

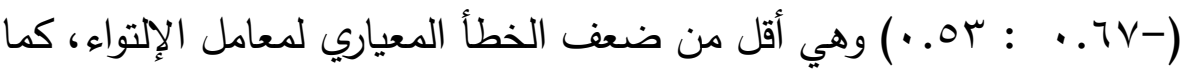

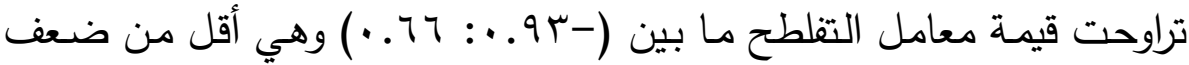
الخطـأ المعيـاري لمعامـل التفلطح، مدـا يشـير إلـى إعتداليـة توزيـح العينـة في الاختبارات المهارية للعينة قيد البحث. القياس القبلي: تم إجراء القياس القبلي لعينة البحث الأساسية وعددها ( • (ب) طالب من طـلاب الفرقة الثالثة شـعبة التدريس تخصص كرة اليد فى الفترة من الاثتين

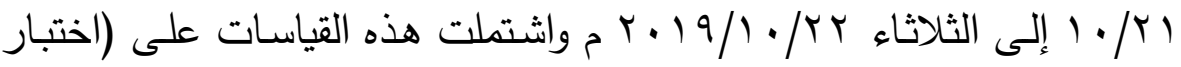
التحصيل المعرفي - الاختبارات المهارية). 
تنفيذ البرنامج:

تم تنفيذ البرنامج التعليمي على أفراد المجموعة التجريبة، واستغرق ذلك

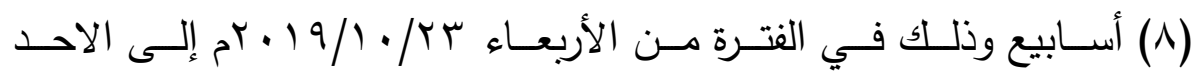
$\cdot r+19 / 1 r / 10$ القياس البعدي : (الباس

بعـد الانتهاء مـن تتفيـذ البرنـامج تـم إجـراء القياسـات البعديـة للمجموعـة التجريبية فى نهاية المدة المقررة لتتفيذ البرنامج التعليمي حيث تم ذلك فى الفترة

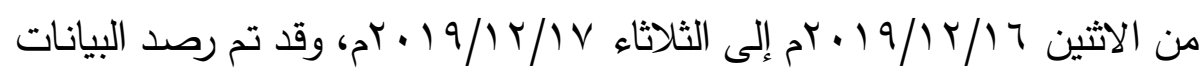

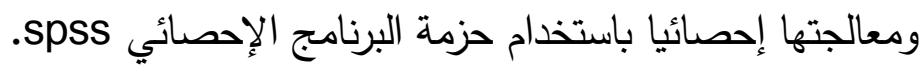
عرض ومناقشة النتائج :

لتحقيق أهداف البحث والتحقق من صحة الفروض يتم عرض وتفسير النتائج فيما يلي : ا- النتائج الخاصـة بمستوي أداء المهارات (الهجومية- الدفاعية) قيد البحث

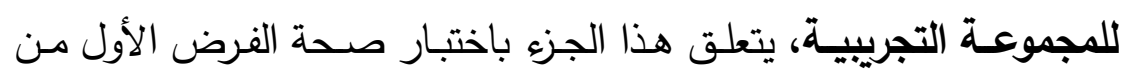

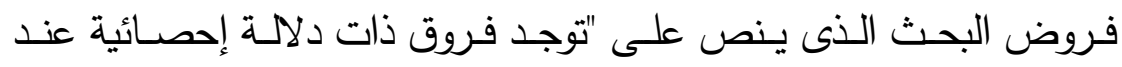
مستوى (0 . . •) بين متوسطي درجات القياسين القبلي والبعدي للمجموعـة

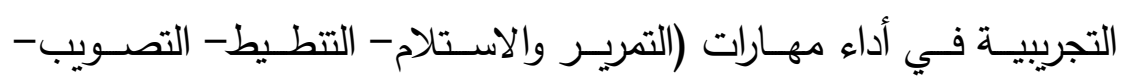
التحركات الدفاعية) لصالح القياس البعدي وجدول (س I) يوضح هذه النتائج. 


$$
\text { جدول (1) (1) }
$$

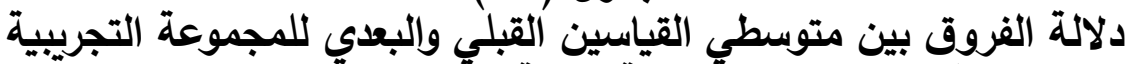

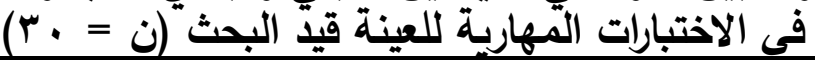

\begin{tabular}{|c|c|c|c|c|c|c|c|c|}
\hline \multirow[b]{2}{*}{ قيمة } & \multirow[b]{2}{*}{ التصسبسن } & \multicolumn{2}{|c|}{ بـعدي } & \multicolumn{2}{|c|}{ قبلي } & \multirow[b]{2}{*}{ القياسدة وحدة } & \multirow[b]{2}{*}{ المتغيرات } & \multirow[b]{2}{*}{ م } \\
\hline & & المعياريـي & المتوسطابي & المعياريـي & المتوسطابسي & & & \\
\hline *หา.T & $1 . \varepsilon . \vee 0$ & T.rV & $r \leqslant . \leqslant r$ & $1 . \leqslant 7$ & 11.94 & & التمرير والاستلام & 1 \\
\hline *Y Y.$\varepsilon$. & VY.VT &. .11 & $11 . r v$ & $1 . V V$ & 19.74 & & التنطيط & r \\
\hline *IV.Vo & 198.71 &. .79 & $\varepsilon . Y V$ &. .71 & $1 . \leqslant \pi$ & & التصويب & r \\
\hline$* \mid 9 . \leqslant 1$ & $194 . \leqslant 1$ & $1 . r$. & 1.9 . & $1 . . r$ & $r . . r$ & & التحركات الدفاعية & $\varepsilon$ \\
\hline
\end{tabular}

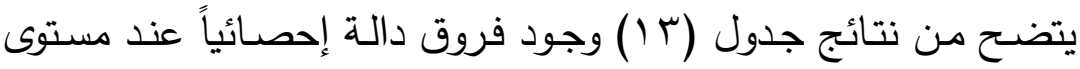
(0 . . ) بين متوسطي درجات القياسين القبلي والبعدي للمجموعـة التجرببية لصالح متوسط القياس البعدي في الإختبارات المهارية للعينة قيد البحث، حيث

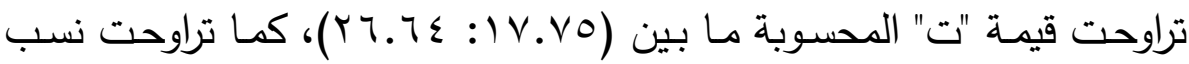

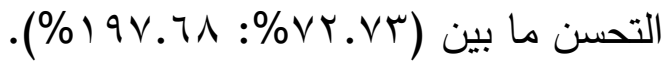

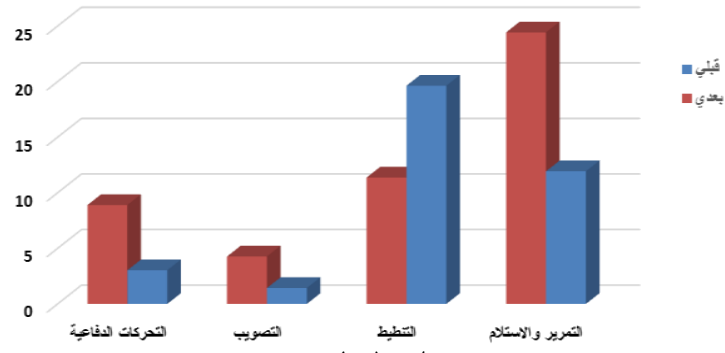

شكل (1) (1)

دلالة الفروق بين متوسطي القياسين القبلي والبعدي للمجموعة التجرببية

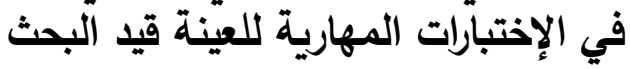

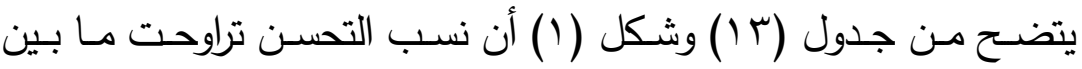

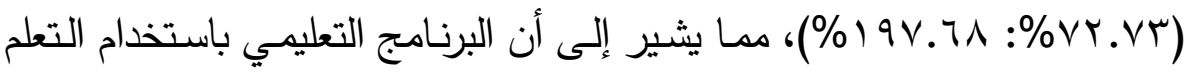

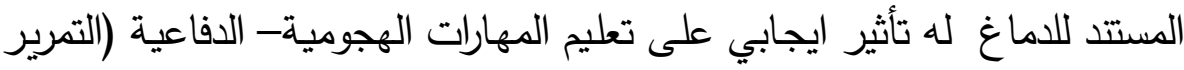

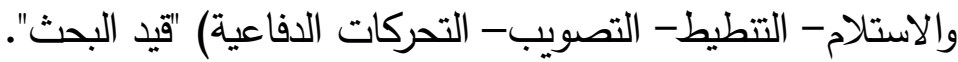




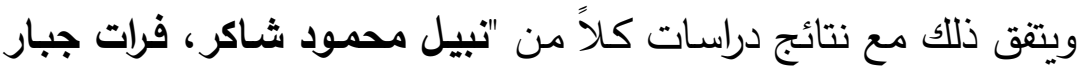

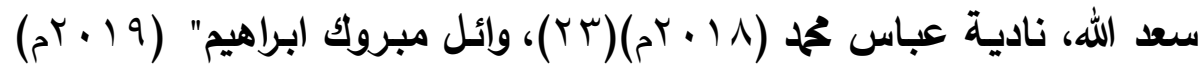

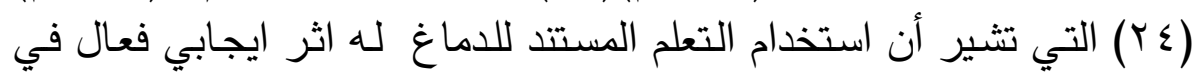
تعليم المهارات الحركية.

ويعزو الباحث التأثير الايجابي للبرنامج قد يرجع إلى ما تضمنه محتوى التهات

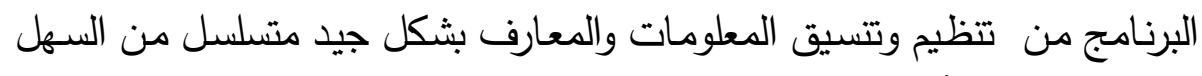

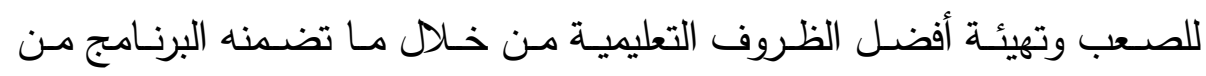

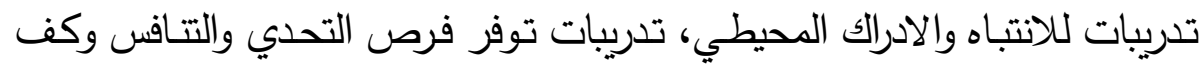

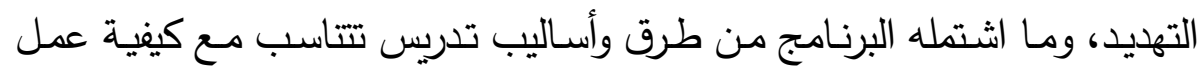

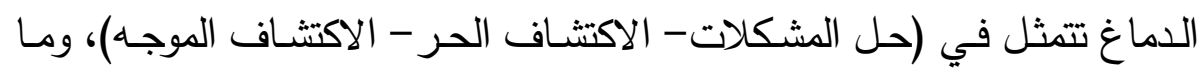

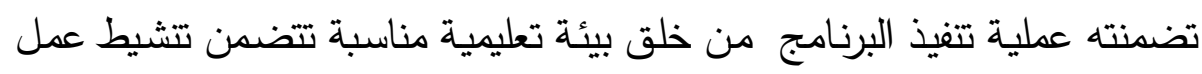

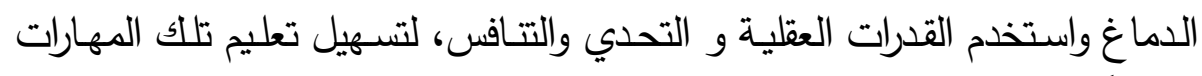

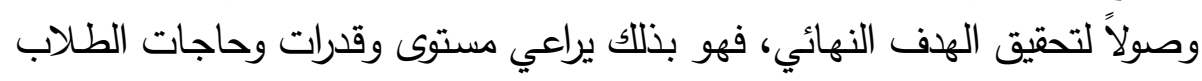

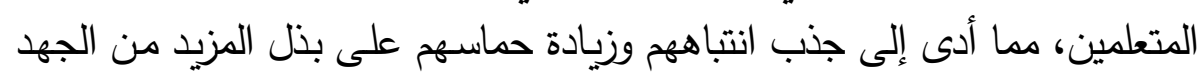

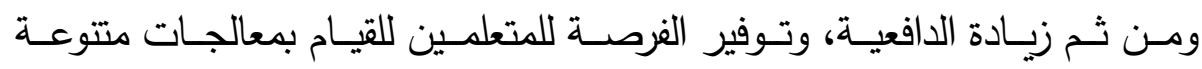

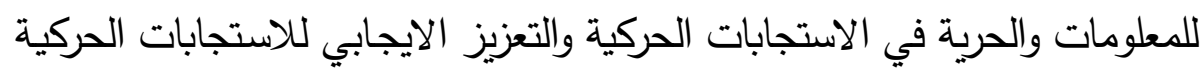

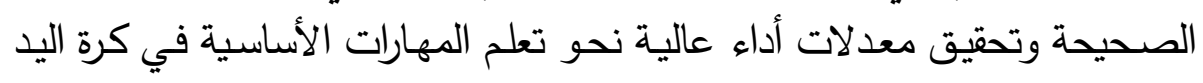
"قيد البحث".

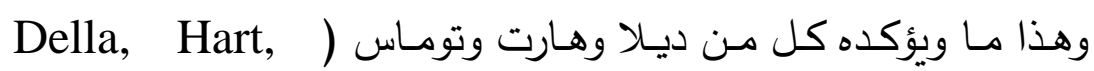

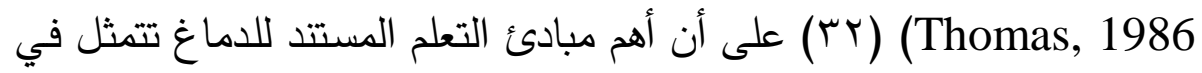

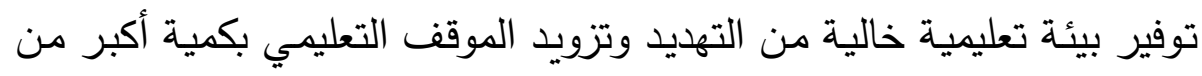

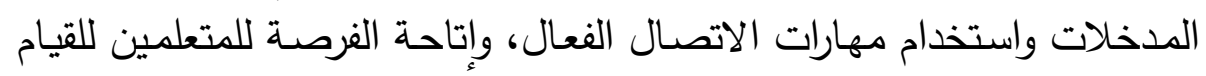

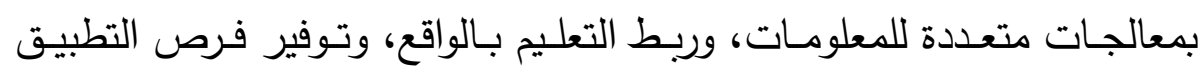

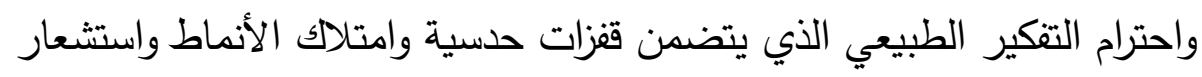

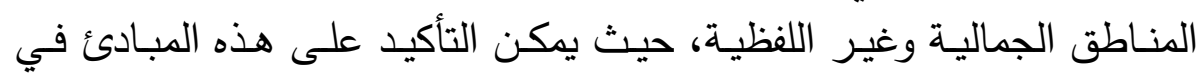

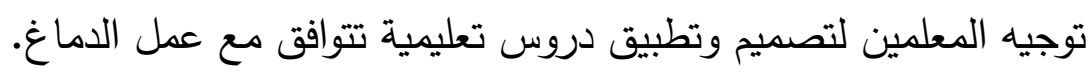




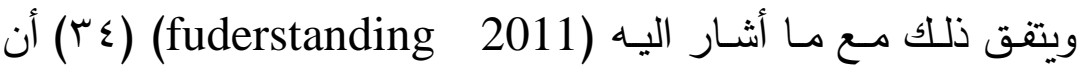

نظرية التعلم المستتد للدماغ تؤكد أن كل فرد قادر علي التعلم اذا توفرت لـه

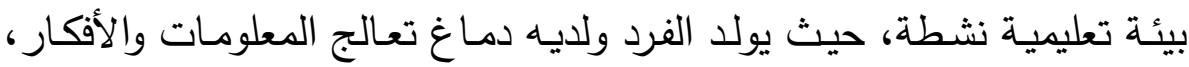
ولكن التعلم التقليدي يعمل غالبا علي الحد من قدرة الدماغ من خلال التجاهل والتثبيط، أو المعاقبة والتخويف لفئي

ومن خلال عرض وتفسير ومناقثة النتائج الواردة بجدول (rا) تتحقق صحة الفرض الأول والذي ينص على "توجد فروق ذات دلالة إحصائية عند

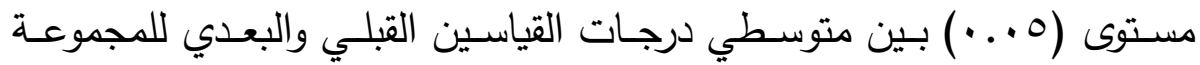

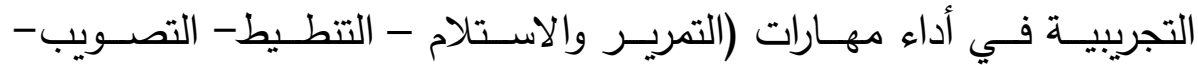
التحركات الدفاعية) لصالح القياس البعدي".

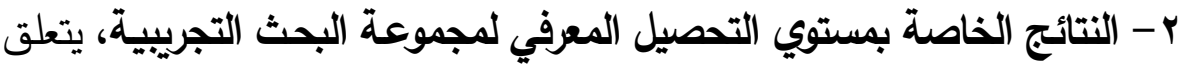
هذا الجزء باختبار صحة الفرض الثاني من فروض البحث الذى ينص على" توجد فروق ذات دلالة إحصائية عند مستوى (0. . ) بين متوسطي درجات القياسين القبلي والبعدي للمجموعـة التجريبية في مستوي التحصيل المعرفي لصـالح القياس البعدي" وجدول (ـ () التالي يوضـح دلالية الفروق بين متوسطي القياس القبلي والبعدي في متغير التحصيل المعرفي

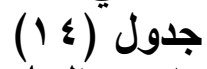

دلالة الفروق بين متوسطي القياسين القبلي والبعدي للمجموعة التجريبية

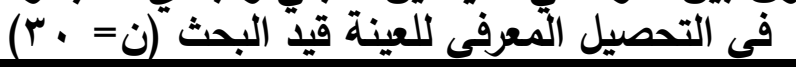

\begin{tabular}{|c|c|c|c|c|c|c|c|}
\hline \multirow{2}{*}{$\begin{array}{l}\text { قيهة) } \\
\text { (ت) }\end{array}$} & \multirow{2}{*}{ التسبة } & \multicolumn{2}{|c|}{ بعديم } & \multicolumn{2}{|c|}{ قبلير } & \multirow[b]{2}{*}{ القياسل } & \multirow[b]{2}{*}{ المتغيرات } \\
\hline & & الالنمراذي & المستوسير & الالندرافي & المسابير & & \\
\hline " & 1.0 .7$. & $\overline{l r . . r}$ & $\overline{r r . . r}$ & r.ro & $17 . . \mathrm{V}$ & & التمبيل الشروني \\
\hline
\end{tabular}

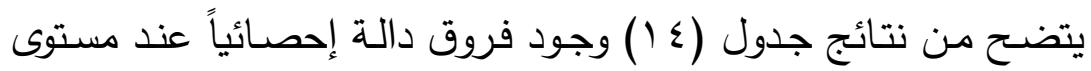
(0. . ) بين متوسطي درجات القياسين القبلي والبعدي للمجموعة التجريبية 
لصالح متوسط القياس البعدي في اختبار التحصيل المعرفي للعينة قيد البحث،

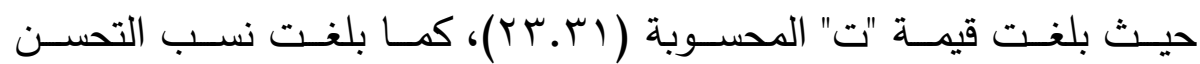

$$
\cdot(\%) \cdot 0.7 \cdot)
$$

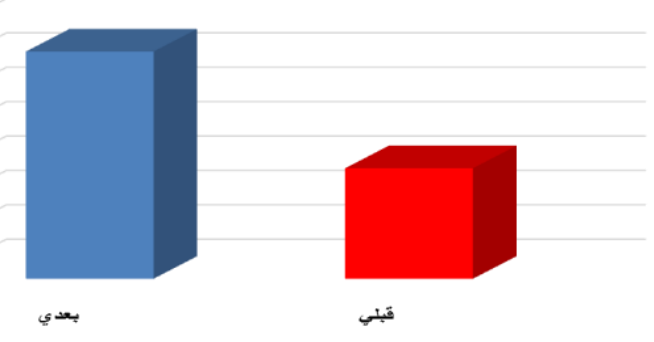

شكل (r)

دلالة الفروق بين متوسطي القياسين القبلي والبعدي للمجموعة التجريبية

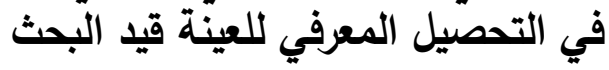

ويرجع الباحث نسبة التحسن في القياس البعدي للمجموعة التجريبية في

مستوي التحصيل المعرفي الي ما احتوي عليه البرنامج التعليمي المقترح باستخدام

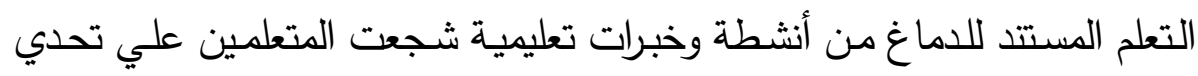
تفكيرهم لاستيعاب المستويات المعرفية التي استهوفها البرنـامج، والتي سـاعدتهم علي تتظيم وتصـنيف خبـراتهم حسـب صـفاتها المشـتركة، ومكنتهم مـن تقسير العلاقات بين المفاهيم وفق خبرات متتابعـة حتي يسـهل ربطها بمحتوي الوحدة، بالإضافة إلى استخدام طرق وأساليب متتوعة تتتاسب مع عمل الدماغ والتي وفرت بيئة تعليمية تتسم بالتحدي من غير تهديد، مما أدي إلى اثارة دافعية المتعلمين، ويظهر ذلك من خـلال اهتمـام الطـلاب وتفـاعلهم الواضـح أثتاء تطبيق البرنـامج، وخاصـة حين يتتم استخدام أسـاليب تدريس جديدة، وتغيير بيئة التعلم، واستخدام أسـاليب تدريس منظمـة، كأسـلوب حل المشكلات والاكتشـاف الحر ، والاكتشـاف

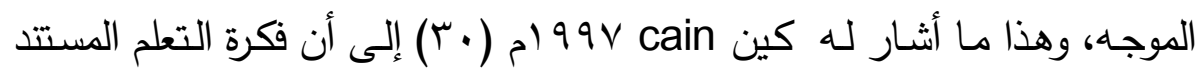

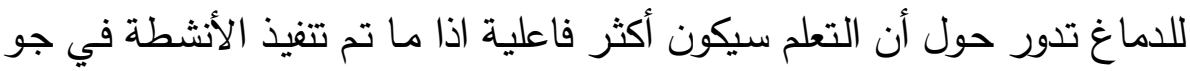


متوافق مع الطريقة التي يتعلم بها الدماغ، وأن التعلم سيكون أكثر فاعلية اذا ما تم في البيئة الطبيعية للمتعلم بحيث يشكل تحديا من غير تهديد، فهو يركز علي كيفية تعلم الدماغ، وينظم التدريس وفق هذه القواعد.

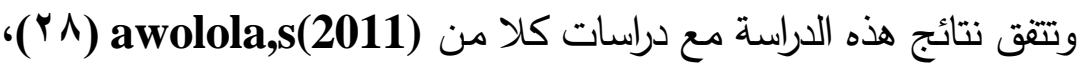

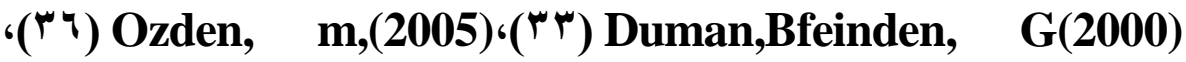
(rv)Pinketo,D (2002) والتي أكددت على أن التعلم المستتد للدماغ يعمل علي تتمية التحصيل المعرفي وزيادة الدافعية للتعلم. ومن خلال عرض وتفسير ومناقشة النتائج الواردة بجدول ( \& 1) تتحقق صحة الفرض الثاني والذي ينص على "توجد فروق ذات دلالة إحصائية عند مسـتوى (0. . • ) بـين متوسـطي درجـات القياسـين القبلي والبعـي للمجموعـة التجريبية في مستوي التحصيل المعرفي لصالح القياس البعدي" | الاستتتاجات:

في ضـوء أهداف البحث، وفى حدود عينته، ومـن واقـع النتـائج التي توصلت إليها الاراسة تم استنتاج الاتي:

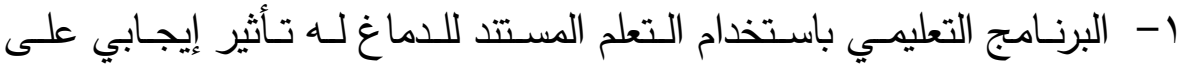

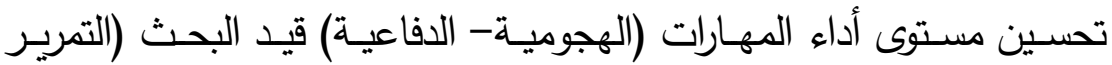
والاستلام - التتطيط- التصويب- التحركات الدفاعيـة) حيث تراوحت نسبة

$$
\text { التحسن ما بين ( }
$$

r- البرنـامج التعليـي باسـخدام التعلم المسـتـد للـدماغ لـه تـأثير إيجـابي علـي تحسين مستوي التحصيل المعرفي لطلاب شعبة التدري تخصص كرة اليد

$$
\text { حيث بلغت نسبة التحسن ( • 0.7 • (\%). }
$$

التوصيات:

1- تضمين موضـوع عن أسـاليب تدريس التربية الرياضية في ضـوء نظريـة التعلم المستتد للدماغ في مقرر طرق تدريس التربية الرياضية. 
r- استخدام البرنامج التعليمي المقترح في تعليم مهارات كرة اليد (الهجوميةالدفاعية).

r- اجراء ابحاث أخري مماثلة لتعليم المهارات الاساسية في مختلف الألعاب

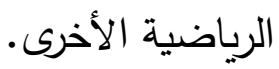

\section{$(($ (المراجه)}

\section{أولاً: المراجع العربية}

1 - أحمد السيد الموافي خطاب: "بناء اختبار معرفي في الكرة الطائرة لتلاميذ المرحلة الإعدادية بمحافظة الدقهلية"، المجلة العلمية لعلوم التربية البدنية والرياضـة -مصر العدد (0)، كلية التربية الرياضية. جامعه المنصورة. 0 . . rم. r - اشرف عثمان عبد المطلب (9 . . r): "بناء اختبار معرفي في كرة القدم لطلاب كلية التربية الرياضية شعبة التدريس بجامعة

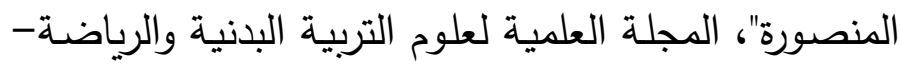

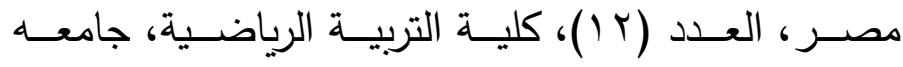

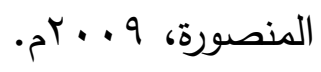

ب- أثـرف تحمد سـد الـاخاخني: تأثير برنامج تدريبي بالنظام الثـامل علي تتمية

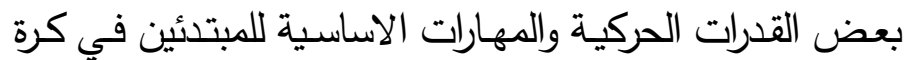

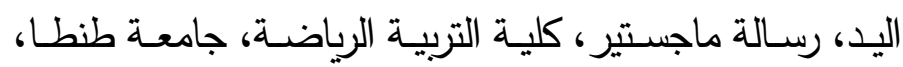

$$
\text { . } 9
$$

צ - بني عطا، احمد مصطفى (9 . . ץ): قياس المستوى المعرفي للثقافة الرياضية عند طلبة الجامعة الأردنية، مجلة مؤتة للبحوث والدراسات، سلسلة العلوم الإنسانية والاجتماعية، المجلد

$$
\text { الرابع والعشرون، العدد الأول. }
$$

ه- تغريـا البـاوي: فاعلية برنامج تعلمي - تعليمي مبني على التعلم المستند

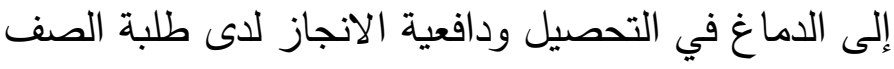




\section{4}

الخامس الأساسـي في مديريـة تربيـة عمان الرابعـة، رسـالة

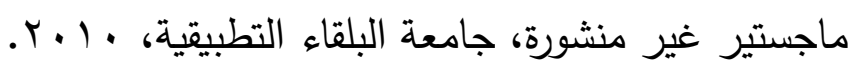

צ- حنـان محمد أحمـد: تأثير برنـامج مقترح للتدريب العقلي علي تعلم مهارة

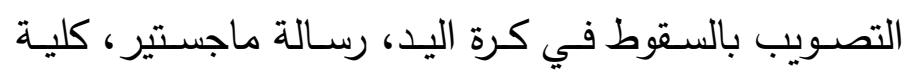

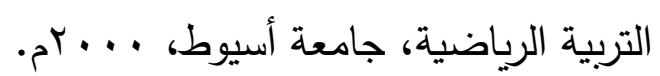

- حنان كحمد أحمد: أثر استخدام بعض أساليب التدريس على مستوى الأداء

لبعض المهارات الأساسية في كرة اليد لطالبات كلية التربية

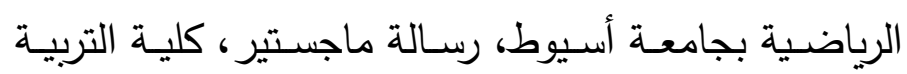

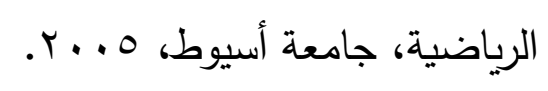

^- خالد حمـودة: الهجوم والدفاع في كرة اليد، دار المعارف، طاه، القاهرة،

$$
\text { .r. }
$$

9 - عماد الدين عباس أبوزيد: تطبيقات الهجوم في كرة اليد (تعليم- تدريب)

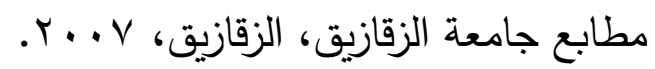

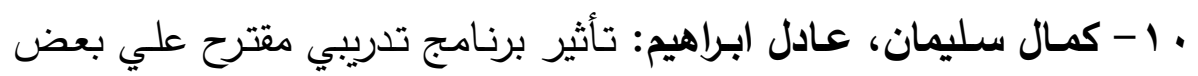

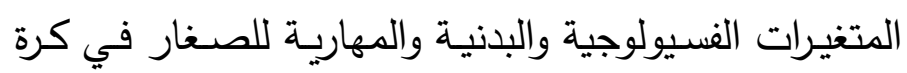

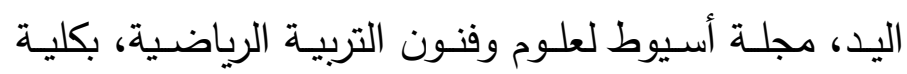

$$
\text { التربية الرياضية، جامعة أسيوط، و99 أم. }
$$

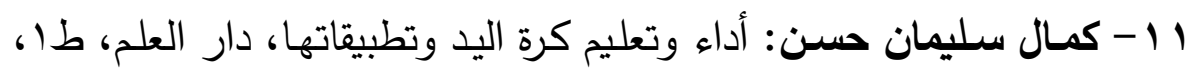

$$
\text { .r. . V }
$$

r ا - كمال عبد الحميد، محمد صبحي حسانين: رباعية كرة اليد الحديثة، الجزء

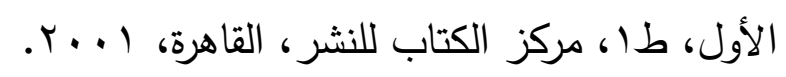

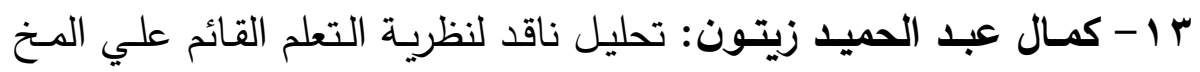

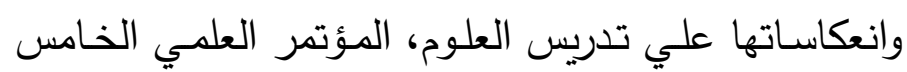

للجمعية المصرية للتربية العلمية (التربية العلمية والمواطنة) 
9 يوليو - ( اغسطس، كلية التربية- جامعة عين شمس،

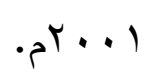

ع ا - ليلى السيد فرحات (1 . ץ): القياس المعرفي الرياضي، القاهرة، مركز

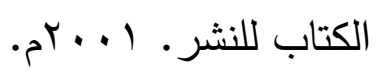

ه - محسن إسماعيل إبراهيم: الناهج في بناء المناهج مذكرة غير منشورة،

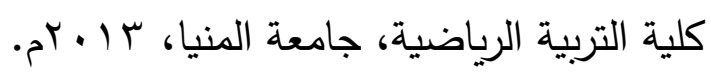

ד 1 - عحمد توفيق الوليلي: "كرة اليد (تعليم، تدريب، تكنيك)"، طج، دار الفكر

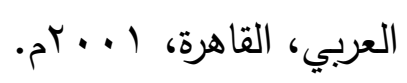

I - محمود عبد الحليم عبد الكريم: "المعاصر في تدريس التربية الرياضية"، كلية

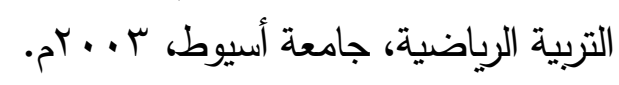

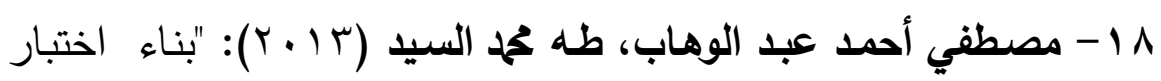
معرفي في رياضـة تنس الطاولة للمرحلة التمهيدية بكلية التربية الرياضية جامعة أسيوط" لمؤتمر العلمي الدولي حول علوم الرياضـة في قلب الربيع العربي- كلية التربية الرياضية بجامعة أسيوط.

9 - 19

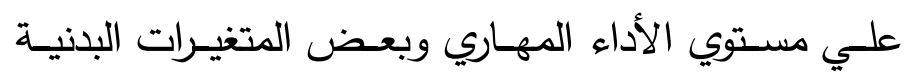
والفنيولوجية للاعبي كرة اليد، رسالة دكتوراه، كلية التربية

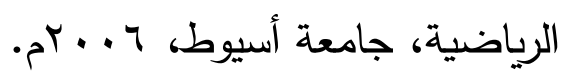

• ץ - منير البعلبكي: المورد (قاموس انجليزي- عربي) دار العلم للملايين،

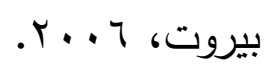

اب - منير جرجس إبراهيم: كرة اليد للجميع والتدريب الشامل والتميز المهاري،

$$
\text { دار الفكر العربي، القاهرة، ع ـ . . بم. }
$$


r r - ناديـة سـميح السـلطي: التعلم المستند للدماغ، طاه دار المسيرة للنشر

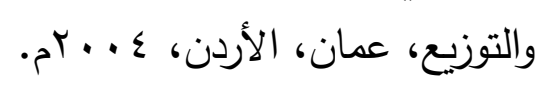

r r - نبيل محمود شاكر، فرات جبار سعد الله، نادية عباس عحمد: تأثير منهج تعليمي وفقا للتعلم المستند الي الدماغ في اتقان مهارة الكب

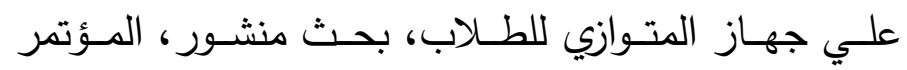
العلمي الدولي الأول (بالرياضة ترتقي المجتمعات وبالسـلام

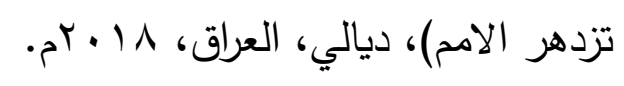

ع r - وائـل مبروك ابراهيم مبروك: تأثير استخدام بعض استراتيجيات التعلم المستند الي الدماغ علي التحصيل المعرفي ومستوي أداء بعض المهارات الأساسية في مادة المنازلات لطلاب الفرقة

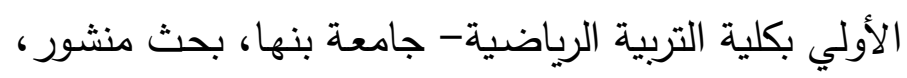

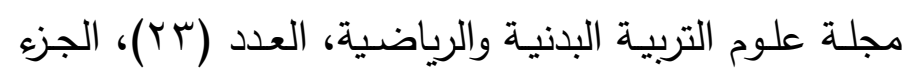

$$
\text { . } 19 \text {. } 19 \text { ( }
$$

ه - ولـيم عبيــ وعزو عفانـة: التفكير والمنهاج المدرسي، مكتبـة الفـلاح للنشـر

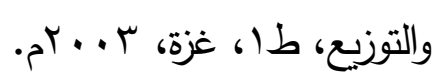

צr - يوسـف حتي، الخطيب أحمد: قاموس حتي الطبي للجيب (انجليزي- غزئ

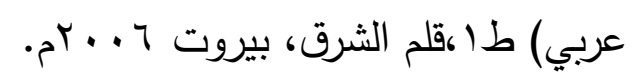

نانباً: المراجم الإمنـبـبة فربة

27- Alflimbani, D. (2014): The impact of training program based on brain based and motivation level of proficiency in the development of skills beyond learning and academic achievement the development of higher- order thinking skills they have and their attitudes towards. 
(unpublished Doctoral dissertation). Amman Arab University, Jordan.

28- awolola,s (2011): effect of brain-based learning strategy on students, achievement in senior seconedary school mathematics in dto state, nigeria cypriot journal of educational sciences, z (1),91-106

29- Bucko, R., (1997): Brain basics: Cognitive psychology and its implications for education. ERS Spectrum. Retrieved from: http:// scholzr. Lib. vt. edu/theses/ available/ etd 1129999142300

30- Caine, R.N, Caine, (1997): Education on the edge of possibility. Alexandrai, VA: Association for supervision and curriculum development.

31- David Sousa (2008): How the Brain Lear Mathematics, Thousnd Daks CA, US: Corwin press, 168.

32- Della, N. Hart, L\& Thomas, E (1986): Huge learning jump show potency of brain- based in struction. Phi Delta kappan, 86(2), 143- 148.

33-Duman, Bfeinden, G(2000) facilitating reflective thinking in counselor education, souece counselor education \&supervision, 40 (2)12-82 
34- fuderstanding (2011): brain-based learning available on line at http-www fuderstanding -com theory- brain-based- learning (accessed 8 octopar, 2014)

35- Hart, Lesile (1986): A response: All thinking paths lead to the brain educational leadership, Retrieved from: http:www.besu.edu/departments/grad/greadstep/ taresource. htim.

36- Ozden, $\mathbf{m}$, (2005): the effect of brain based learning on a cademic achievement and retention of knwledein science course,Journal of scinece education, 12(1),65-78

37- Pinketo, D (2002): Using brain-based learning techniques in high school science ,Teaching of change fall,49(1),44-60. 